\title{
ŠIBENICE U PŘIMDY. ARCHEOLOGICKÝ VÝZKUM OBJEKTU SE ZVLÁŠTNÍM SYMBOLICKÝM A SOCIÁLNÍM VÝZNAMEM
}

\author{
PETR SOKOL
}

\begin{abstract}
Abstrakt: Šibenice v Přimdě, objevená v roce 2006 a archeologicky zkoumaná v roce 2014, patř́ k nepočet$n y ́ m$ v reliktech dochovaným objektům tohoto typu v Čechách. Raně novověké šibenice predstavuji dobově kulturně a sociálně vyhraněně vnímaný objekt, o němž jsou $k$ dispozici informace prevážně z písemných pramenů. Článek se v úvodní části zabývá charakteristikou šibenic z tohoto pohledu a výpovědním potenciálem hmotných pramenů ziskaných jejich archeologickým výzkumem. Kromè otázky možností a přnosu archeologie k poznáni nejen objekti šibenic jako takových se tato část článku dotýká i otázek souvisejicich $s$ výkonem hrdelního práva, přistupem $k$ marginalizovaným jedincuim a nakládáním s jejich pozůstatky. Druhá část článku je věnována samému výzkumu šibenice v Přimdě a jeho vyhodnocení.
\end{abstract}

Klíčová slova: šibenice - popraviště - pohřebni ritus - hrdelní tresty - právní archeologie - raný novověk-Přimda.

The Gallows near Přimda. Archaeological Research into a Feature of Special Symbolic and Social Importance

\begin{abstract}
The gallows in Primda discovered in 2006 and archeologically investigated in 2014 belongs with the rare relics of structures of this type preserved in the Czech lands. Early modern-age gallows are features of special cultural and social importance, the information about which mostly comes from written sources. The article opens with the characterization of gallows from this perspective and discusses the informative potential of material sources acquired by their archaeological research. Apart from the possibilities and contribution of archaeology to the study of gallows as such, this part of the article also touches upon questions connected with capital punishment, the approach to socially rejected individuals and the manipulation with their remains. The second part of the article focuses on the research into the gallows in Primda and its assessment.
\end{abstract}

Key words: gallows - place of execution - burial rite - capital punishment - legal archaeology - early modern age - Přimda.

Pozůstatky šibenic představují specifické objekty s bohatým symbolickým a výrazným sociálním významem. Šibenice díky svému záměrně nápadnému umístění tvořily krajinné dominanty v zázemí řady měst a vzhledem k jejich účelu byly vnímány vyhraněně jakožto místa se zvykově i právně vymezenými pravidly pohybu a kontaktu obyvatel s vlastním objektem šibenice. V tomto smyslu byla šibenice $\mathrm{s}$ nejbližším okolím na jedné straně místem obnovování rádu, který byl trestaným deliktem narušen, na straně druhé pak místem zvyklostmi zapovězeným a zneuct’ujícím mimo dobu exekucí. Do symbolického obsahu popraviště se promítalo vnímání trestu nejen jako demonstrace moci a práva, ale i jako veřejného představení, které zejména od dob baroka mohlo nabývat charakteru až lidové slavnosti. Současně šlo o místo spjaté s pověrečnými představami a lidovou magií v úzké souvislosti s charakterem místa, kde byli lidé zbavováni života a kde byla zahrabávána těla sebevrahů. Právě ukládání těl popravených osob a sebevrahů, i když s minimálním či mnohdy bez jakéhokoli ritu v užším smyslu (Sokol 2008a; 2010; 2010b; dále souhrnněji např. Duma 2010; pro srovnání s raně středověkou situací souhrnněji např. Reynolds 2009; 2014; Štefan 2009), a tedy charakter zvláštního pohřebiště pro nejbližší okolí šibenice, tvořilo další složku symbolické náplně středověkých a zejména raně novověkých popravišt'. V sociální sférée reprezentují šibenice objekty s vyhraněnou vazbou na některé sociální a profesní skupiny. Pomineme-li účast příslušníků cechů stavebních řemesel podílejících se na stavbách a opravách šibenic, představovala tato místa výlučné působiště katů, tedy jedné z nejrozporuplněji vnímaných profesních skupin ze strany ostatního obyvatelstva. Vykonávanými formami hrdelních trestů (nejčastěji oběšení) v návaznosti na povahu trestaných deliktů nesloužily šibenice obvykle pro trestání všech sociálních skupin. Šibenice lze tedy z výše uve- 
dených př́ičin považovat za kulturně a sociálně vyhraněně vnímaný objekt, čemuž neodporují ani dosavadní archeologická zjištění. ${ }^{1}$

Šibenice, potažmo historická popraviště obecně a výkon hrdelních trestů, jsou přirozeně jedním z témat, k němuž primárně existují písemné a obrazové prameny, zejména pak pro období raného novověku. Př́nos archeologie může spočívat nejen v poznání hmotných pramenů k tomuto tématu, ale i v poskytnutí jinak nezjistitelných dat a metodiky jejich zpracování pro nově nastolované či řešené otázky širšího archeologického, historického a antropologického výzkumu (např. pro období raného stř̌edověku Reynolds 2009; 2014). Archeologické výzkumy těchto památek hrdelního soudnictví potvrzují informace z písemných pramenů, přinášejí specifický pohled na konkrétní okruhy otázek, jež jsou z písemných pramenů známy, mimo to však poskytují zcela nové informace nebo otevírají otázky v historických pramenech a literatuře neřešené. Primární jsou informace o vzhledu, intenzitě využití a datace (pokud jsou známy písemné zprávy, má archeologická datace vzhledem k svým limitům jen potvrzující charakter), další skupiny představují informace o místě a prostorových vztazích, funkčním členění a organizaci prostoru, o způsobech trestů (opět v komparaci s písemnými prameny), o ,pohřebním ritu“ popravených osob, a tedy $\mathrm{v}$ důsledku o vztahu společnosti k marginalizovaným skupinám a jedincům prostřednictvím specifického zacházení s lidskými ostatky.

Z hlediska archeologie představují šibenice nevelký a půdorysnou strukturou nekomplikovaný objekt, jehož stratigrafie nebývá výrazně narušena pozdějšími aktivitami. V případě výzkumů šibenic se navíc nacházíme v situaci, kdy z písemných pramenů známe alespoň zčásti děje, které se v těchto místech odehrávaly, jejich protagonisty i obecná provozní pravidla. Zdánlivá jednoznačnost interpretace nálezových situací, především hmotných nálezů však bere za své v důsledku větších nároků, podrobnějších hledisek a konkrétnějších otázek, které v důsledku této zdánlivé jednoznačnosti problematiky a vyhraněnosti sociálního kontextu vznášíme a uplatňujeme.

V těsné blízkosti šibenice se mohl pohybovat pouze omezený okruh osob, stejně tak byl úzký i okruh příležitostí, za kterých k tomu mohlo docházet. Tato skutečnost umožňuje zpravidla nepočetné a skladbou se opakující soubory nálezů z výzkumů těchto objektů vztahovat obvykle právě jen $\mathrm{k}$ těmto skupinám nebo osobám a interpretovat je $\mathrm{v}$ souvislosti s několika charakteristickými okruhy událostí (obr. 1).

Z hlediska interpretace jsou nejjednoznačnějším nálezem z míst využívaných jako popraviště lidské kosti. Způsob zacházení s těly i ostatky popravených osob byl v mnohém specifický a jeho doklady se nemusí omezovat pouze na popravní místa. ${ }^{2}$ Druhou zpravidla jednoznačně interpretovanou skupinou nálezů jsou součásti šibenice představované nejčastěji stavebním materiálem, hřeby, hřebíky, skobami, háky nebo řetězy.

Širší interpretační rozptyl nabízejí však zvířecí kosti. Na základě nálezové situace mohou představovat doklady využívání plochy pohřebiště jako mrchoviště (Mašková 2010, 132; Wojtucki 2009, 213n; Mašková-Michálek 2006, 805) nebo zbytků stravy osob pohybujících se v tomto prostoru, at' již v době fungování šibenice, nebo i později, ovšem před její archeologizací. Vyloučit nelze ani přirozené př́činy bez zásahu člověka. O vztahu k osobám odsouzenců nebo katů lze uvažovat v souvislosti s možností exekuce vykonané nejen na člověku, ale doprovodně s ním i na zviřreti, známé z písemných pramenů. Tato možnost však pravděpodobně nebude statisticky významná.

\footnotetext{
$1 \mathrm{~K}$ šibenicím či historickým popravištím obecně existuje dnes již početná literatura věnující se jak dílčím zpracováním jednotlivých lokalit a výzkumů, tak i souhrnnějšímu zpracování určité oblasti či užšího tématu. Z novější literatury lze uvést mezinárodní sborníky Richtstättenarchäologie s př́spěvky pokrývajícími především prostor střední a západní Evropy (Richtstättenarchäologie 2008; Richtstättenarchäologie 2, 2010, Richtstättenarchäologie 3,2012) nebo obecněji pojaté publikace spojující historické a archeologické bádání a mající úzký geografický vztah k našim zemím (Wojtucki 2009; 2014). Česká archeologická literatura je dosud nepř́liš početná, souhrnněji Sokol 2003a; 2003b; Wojtucki 2005; Mašková 2015; Mašková-Wojtucki 2016; dále např. Mašková-Michálek 2006; Sokol 2008; 2010b; Sokol-Hajšman 2009; 2010; Unger 2014; Pěnička 2014. V posledních letech začala být u nás věnována pozornost topografickým průzkumům menších územních celků v jižních Čechách, viz Fröhlich 2006; 2008; Kováŕ 2008; 2009; Michálek 2006; Vokáč 2011. Tematika tzv. právní archeologie má i svá specializovaná periodika, historických českých zemí se dotýkají např. Pomniki dawnego prawa, vydávané vratislavským spolkem Stowarzyszenie ochrony i badań zabytków prawa (z českých lokalit např. Kovář 2010; Vokáč 2014). Výkon hrdelního práva z historicko-antropologického hlediska např. Dülmen 2001; 2003; k českému prostředí např. Francek 1995; Kreuz 2000; Sokol-Hajšman 2010, 46-50.

2 Že jde o problematiku výskytem zřejmě rozšiřenější a z hlediska interpretace nálezové situace významnější, než by se mohlo soudit na základě zdánlivé marginálnosti tématu, ukazuje např. reinterpretace kostrových hrobů z Čelákovic ve středních Čechách (Mašková 2005; srov. následnou polemiku Špaček 2009; Mašková 2010; Sokol 2010a).
} 


\begin{tabular}{|c|c|c|c|c|c|c|}
\hline $\begin{array}{ll} & \text { Souvislost } \\
\text { Nález } & \end{array}$ & $\begin{array}{l}\text { Objekt } \\
\text { stavby }\end{array}$ & $\begin{array}{l}\text { Osoby } \\
\text { odsouzených }\end{array}$ & $\begin{array}{c}\text { Kat } \\
\text { s pomocníky }\end{array}$ & ŘemesIníci & Diváci & $\begin{array}{c}\text { Pozdější } \\
\text { návštěvníci }\end{array}$ \\
\hline Lidské kosti & & $x$ & & & & \\
\hline $\begin{array}{l}\text { Keramika } \\
\text { - nádoby } \\
\text { - osobní předměty }\end{array}$ & & & $x$ & $x$ & $x$ & $x$ \\
\hline $\begin{array}{l}\text { Předměty z kovu } \\
\text { - součásti stavby } \\
\text { - součásti oděvu } \\
\text { - mince } \\
\text { - osobní předměty }\end{array}$ & $x$ & $x$ & $\times$ & $x$ & $x$ & $\times$ \\
\hline $\begin{array}{l}\text { Předměty ze dřeva } \\
\text { - součásti stavby } \\
\text { - osobní prededměty }\end{array}$ & $x$ & $x$ & $\times$ & $x$ & $x$ & $\times$ \\
\hline Zviŕ̌ecí kosti & & $x$ & $x$ & $x$ & & $\times$ \\
\hline $\begin{array}{l}\text { Jiný materiál } \\
\text { - součásti oděvu } \\
\text { - osobní předměty }\end{array}$ & & $x$ & $x$ & $x$ & $x$ & \\
\hline
\end{tabular}

Obr. 1. Druhy nálezů ze šibenic a jejich interpretační souvislosti. Vztah k posledním třem kategoriím (původcům, událostem) je obvykle méně pravděpodobný či odvislý od plošného rozsahu výzkumu.

Abb. 1. Fundarten vom Galgen und ihre Interpretationszusammenhänge. Der Bezug zu den letzten drei Kategorien (Urheber, Ereignisse) ist gemeinhin weniger wahrscheinlich bzw. ist vom großflächigen Umfang der Grabung abhängig.

Pro příslušnost nálezů součástí oděvů, osobních předmětů a mincí k jednotlivým okruhům osob, a tedy i událostem je podstatný prostorový kontext ve vztahu k šibenici. Zjednodušeně, zatímco u nálezů z interiéru šibenice a z jejího nejbližšího okolí je vysoká pravděpodobnost vztahu předmětů k osobám katů či odsouzenců, nálezy z větší vzdálenosti lze přisoudit divákům exekucí, kteří se do nejbližšího okolí šibenice neměli dostávat. Toto zjednodušené návodné kritérium však neplatí v př́ípadě pozdějších návštěvníků místa, kteří se již nepodřizovali pravidlům určujícím míru kontaktu s objektem šibenice. V případě zlomků keramiky lze snad z úvah o příčině jejich výskytu vynechat pouze souvislost s osobami odsouzenců.

Pro interpretaci existuje tedy relativně omezený okruh možností, vymezený na základě písemných pramenů, přesto ale není zcela jednoznačné vysvětlení (vazba na konkrétní skupinu osob / událost) mnohdy možné. Roli při interpretaci tedy hraje nejen vzdálenost od šibenice, ale samozřejmě i stratigrafický a chronologický kontext nálezu (souhrnná charakteristika movitých nálezů z výzkumů šibenic a jejich výčet viz Sokol 2003, 756-757).

\section{Šibenice v Přimdě}

\section{Geografický a sídelní kontext}

Lokalita se nachází přibližně $1 \mathrm{~km}$ jižně od Přimdy na jižním konci protáhlého návrší Šibeník. Společně s hradním vrchem severně od města tvoři Šibeník dvě dominanty vymezující ploché sedlo, ve kterém se v nadmořské výšce 601 metrů na trase zemské stezky z Plzně do Horní Falce a Norimberka rozvíjelo středověké osídlení (obr. 2 a 3).

Vrch Šibeník je tvořen protáhlým hřbetem ve směru sever-jih se dvěma vrcholky, z nichž na severním (745 m n. m.) stojí meteorologická stanice - pozůstatky př́ípadných starších staveb na této ploše již nejsou patrny. Na základě starších, a ne zcela jednoznačných údajů lze o tomto vrcholku uvažovat jako o místě druhého z přimdeckých popravišt' - stínadel, dochovaných do roku 1790 (Köferl 1890, 416). V západním svahu tohoto severního vrcholku jsou dochovány relikty starší cesty ve směru sever-jih a jejího rozcestí a následného úseku cesty ve směru západ-východ. Dále k jihu je táhlé sedlo, které stoupá k jižnímu vyššímu vrcholku (757 m n. m.), opět protáhlému v severojižním směru, vzdálenému 1,1 km od kostela sv. Jiří v Přimdě (obr. 4). Šibenice, patrná do výzkumu v roce 2014 jako kruhový reliéfní útvar, se nachází severně od nejvyššího bodu tvořeného skalní kupou. Podloží tvoří pararula a migmatit (Česká geologická služba, mapové aplikace). Severně od šibenice se ve směru východ-západ táhne nízký kamenný val indikující dřívější rozsah obdělávané 


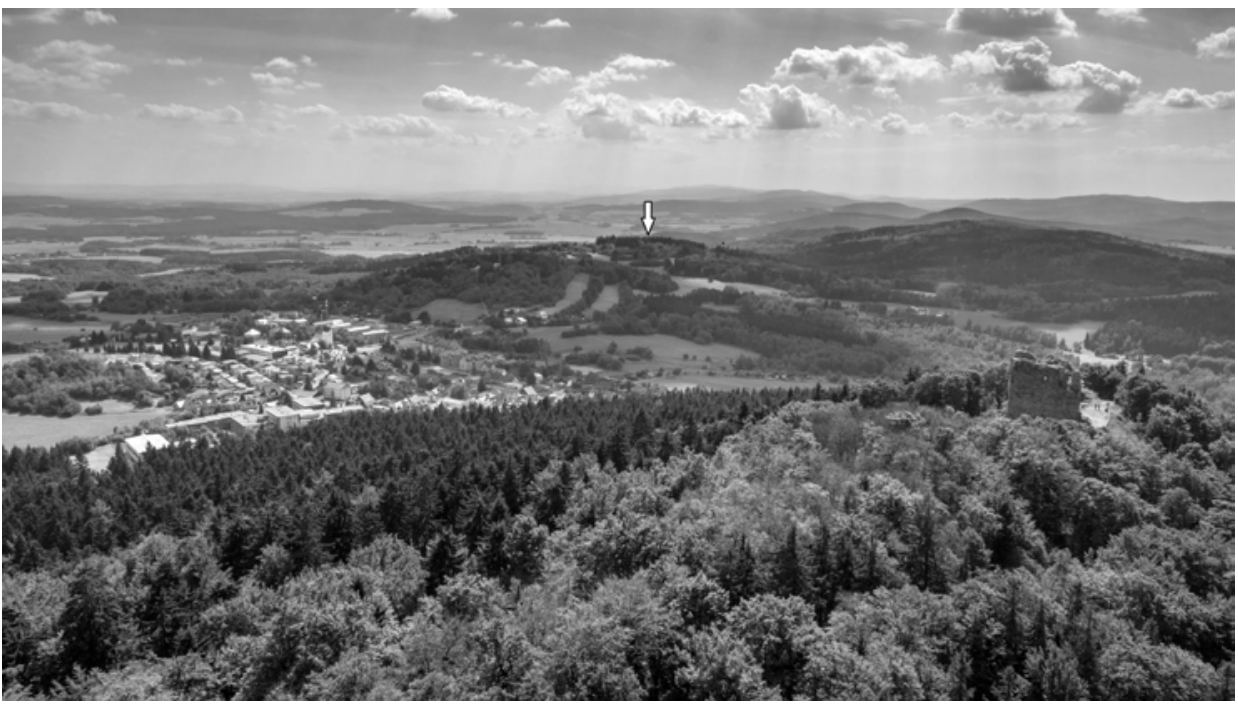

Obr. 2. Přimda, okr. Tachov. Pohled k vrchu Šibeník od severozápadu (poloha šibenice označena šipkou). V popředí návrší s románským hradem, v sedle město Přimda. Foto Vertical Images s.r.o., 2015.

Abb. 2. Přimda, Bezirk Tachov. Blick auf den Galgenberg (Šibeník) von Nordwesten (Lage des Galgens mit Pfeil gekennzeichnet). Im Vordergrund Anhöhe mit romanischer Burg, im Bergsattel die Stadt Př́imda. Foto Vertical Images s.r.o., 2015.

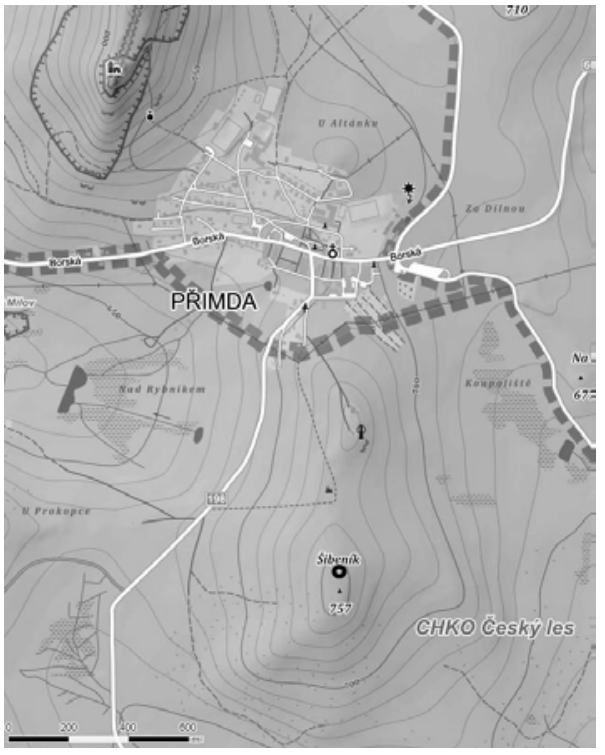

Obr. 3. Přimda, okr. Tachov. Okolí města Přimda s vyznačením polohy šibenice na vrchu Šibeník (černý kroužek). Mapa převzata $\mathrm{z}$ https://mapy.cz.

Abb. 3. Přrimda, Bezirk Tachov. Umgebung der Stadt Přimda mit gekennzeichneter Lage des Galgens auf dem Galgenberg (Šibeník, schwarzer Kreis). Karte entnommen aus https://mapy.cz. půdy, která na rozdíl od současnosti sahala až do blízkosti šibenice (obr. 5). V místech nejblíže reliktům zdiva je tento val přerušen asi $1 \mathrm{~m}$ širokým průchodem.

Na mapě I. vojenského mapování z let 1764-1768 (rektifikace 1780-1783) není toto návrší ještě označeno žádným názvem, temeno vrchu se zdá dosud nezalesněné, název Galgenberg (reflektující způsob využití lokality a existenci šibenice) se objevuje až na mapě II. vojenského mapování z let 1836-1852, přičemž na vrcholku je vyznačena trigonometrická značka. ${ }^{3}$ Název kopce zůstal stejný až do konce 70. let 19. století (III. vojenské mapování z let 1877-1880) a posléze se proměnil v český Šibeník.

Nejasná je trasa původní cesty spojující město se šibenicí. Podle situace na mapách I.-III. vojenského mapování i v současném terénu se zdá, že cesta vedla z obce v západním svahu bližšího vrcholku hřebene a dále přes sedlo přímo k šibenici od severu. Úsek zaniklé cesty, pozorovatelný dosud na jihozápadním svahu severnějšího $\mathrm{z}$ vrcholků hřebene, mohl snad náležet této komunikaci (či jedné její větvi). Tento směr prí́chodu $k$ šibenici podporuje

3 Absence názvu upomínajícího na existenci šibenice na mapách I. vojenského mapování a jeho následné uvedení při II. vojenském mapování není výjimečnou záležitostí. Př́ičinou snad může být nezájem o tyto pomístní názvy při prvním mapování, tedy ještě v době existence některých šibenic či nedlouho po zániku funkce většiny z nich, potažmo o pomístní názvy obecně. 


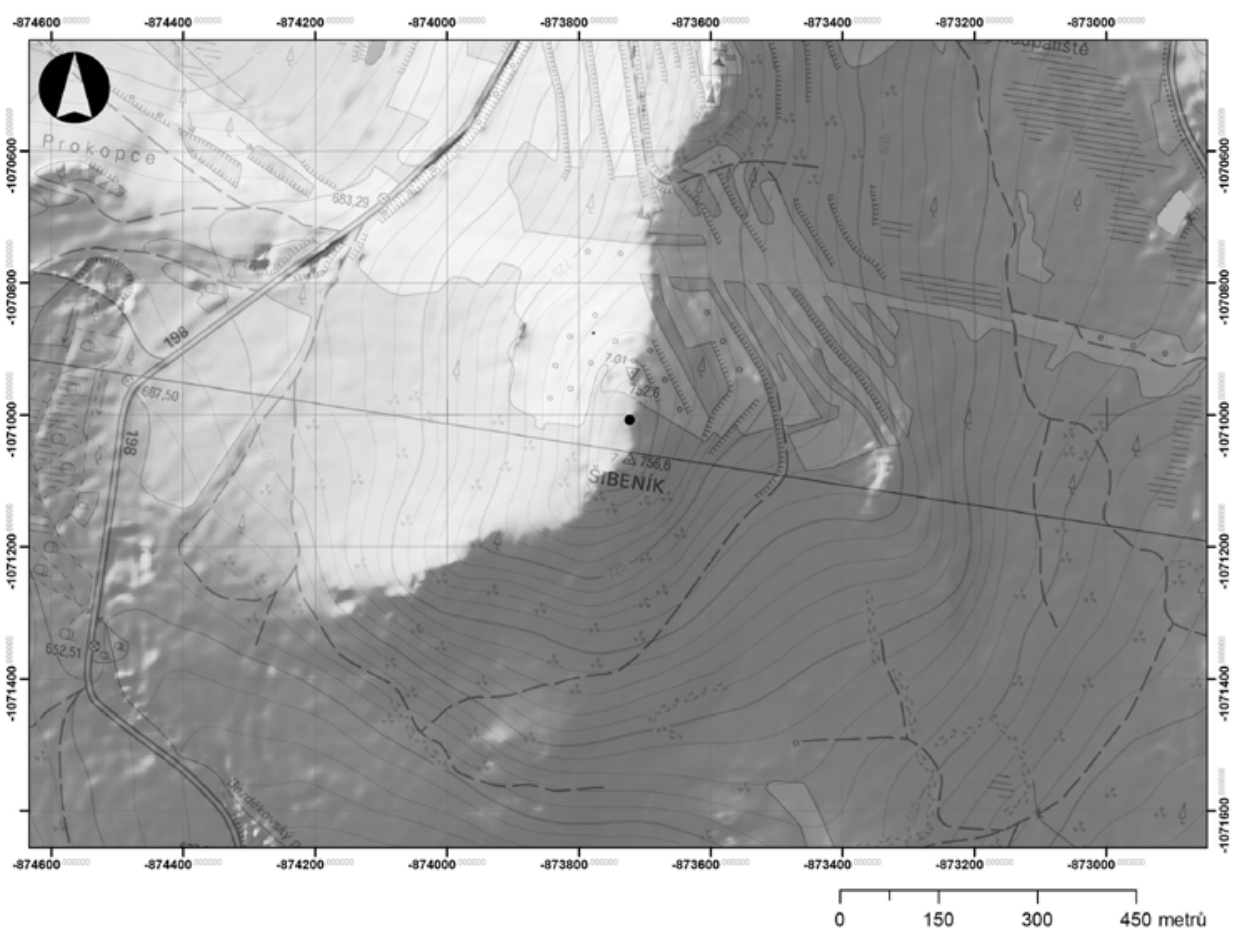

Obr. 4. Přimda, okr. Tachov. Vrch Šibeník s lokalizací šibenice. Zpracoval F. Prekop, 2014.

Abb. 4. Přimda, Bezirk Tachov. Galgenberg (Šibeník) mit Lokalisierung des Galgens. Erstellt von F. Prekop, 2014.

jak morfologie terénu, tak i dosud dobře zřejmý průchod kamenným valem při okraji starších polností severně od šibenice. Jeho časovou i funkční souvislost se šibenicí lze však, stejně jako v případě reliktů zaniklé cesty, pouze předpokládat.

Na digitálním modelu terénu $\mathrm{z}$ dat leteckého laserového skenování jsou patrné i relikty cest stoupajících vzhůru západním svahem návrší, jejich směr se však stáčí více $\mathrm{k}$ jihu, pouze jedna přechází přes vrcholek jižně od šibenice i nejvyššího bodu. Nelze proto vyloučit, že i z této strany, od silnice z Přimdy do Nové Vsi, existoval $\mathrm{v}$ minulosti přístup $\mathrm{k}$ šibenici.

Reliéf severního předpolí šibenice byl $\mathrm{v}$ blíže neurčené míře změněn $\mathrm{v}$ průběhu 30. nebo poválečných let 20 . století. Nejpozději tehdy byly svahy vrcholku upraveny do terasovitých stupňñ, do kterých byly zapuštěny prvky betonového pohraničního opevnění. V nepatrných náspech při okraji pastvin jsou dnes pozorovatelné částečně volné střílny, opevnění nenese stopy novějších zásahů. $\mathrm{K}$ systému tohoto hraničního opevnění patří

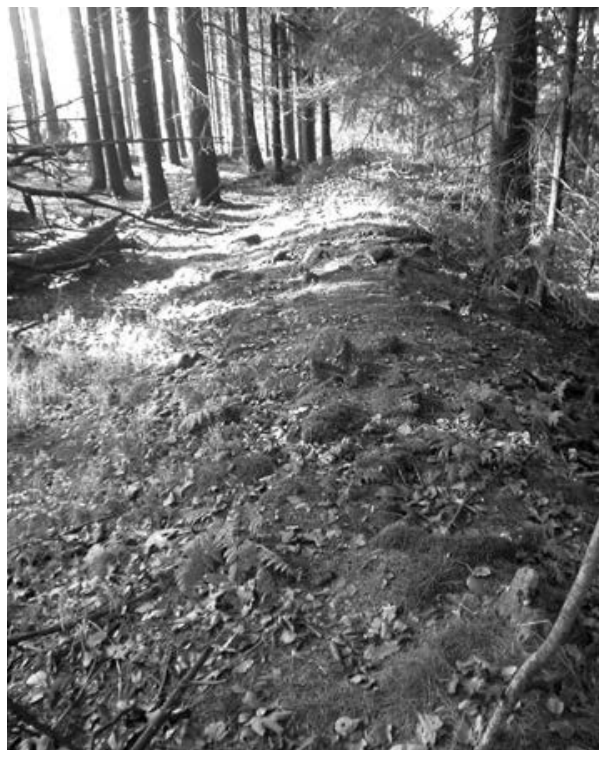

Obr. 5. Přimda, okr. Tachov. Kamenný val vymezující severně od šibenice starší rozsah polností. Pohled od východu. Foto P. Sokol, 2006.

Abb. 5. Přimda, Bezirk Tachov. Steinwall, der den älteren Umfang der Felder nördlich vom Galgen begrenzte. Blick von Osten. Foto P. Sokol, 2006. 
terénní zářezy dobře patrné na digitálním modelu terénu z dat leteckého laserového skenování, viditelné v některých prŕípadech velmi zřetelně i př́ímo v terénu.

Kromě vrchu Šibeník s relikty šibenice je v okolí Přimdy ještě jeden vrch, jehož název je odvozen od šibenice - Šibeniční vrch vzdálený 2,3 km severozápadně (a tedy přes návrší s hradem) od obce. Jeho role ve vztahu k př́ípadné existenci popraviště není zřejmá, vzdálenost od obce je v tomto ohledu př́liš velká, navíc vrch je z pohledu od města schovaný za návrším s hradem. Název kopce může souviset s existencí výstražné šibenice, která bývala stavěna na hranicích panství či zemí a nebyla primárně určena k výkonu trestu.

\section{Hrdelní právo v Přimdě}

Na základě výsledků terénního průzkumu a drobné zjišt’ovací sondáže v roce 2007 byla podniknuta rešerše př́ípadných informací o šibenici v Přimdě v literatuře. V novější literatuře se zmínky o šibenici či hrdelním právu v Přimdě neobjevují. Naopak v již starší práci J. Köferla (1890) jsou obsaženy údaje potvrzující existenci šibenice v poloze „Galgenberg“. Autor uvádí, že stopy šibenice, po které vrch nese jméno, jsou (v době vydání díla) v této poloze patrné v podobě základového zdiva. Kromě toho uvádí, že na dalším vrchu stávala stínadla, zachovaná do roku 1790 (Köferl 1890, 416). Uvedeno je i několik případů hrdelních trestů na těchto popravištích vykonaných: 14. března 1721 byla st’ata Margareta Zeitzin, rozená Schästlerin, 14. ledna 1726 byl oběšen Hans Rauch, 7. srpna 1743 byla st’ata Kunigunde Rachtmannin, přičemž následně bylo její srdce probodnuto kůlem a tělo zahrabáno (Köferl 1890, 416-417).

Vzhledem k morfologii okolí Přimdy je nejpravděpodobnější, že tato stínadla stávala na severním, nižším vrcholku Šibeníku, tedy blíže k obci. Pokud stínadla stávala skutečně na opačném konci Šibeníku než vlastní šibenice, byly stopy po nich zničeny nejpozději při výstavbě meteorologické stanice či objektů jí předcházejících.

Kromě šibenice a stínadel disponovala Přimda jako sídlo soudu i posledním ze základních objektů souvisejících s výkonem práva - pranýřem, který stával na náměstí. Měl podobu kamenného sloupu s trojbokou špičatou hlavicí, v níž byly umístěny železné prvky k připoutání rukou a těla trestaného (Köferl 1890,417). Alespoň podle pověstí mohou se šibenicí a cestou k ní souviset tř̌i kamenné kř́iže umístěné dnes v obci při silnici na Novou Ves u odbočky k Šibeníku (Durdík 2007, 88-89).

Uvedené údaje ze starší literatury potvrzují interpretaci objektu provedenou zpočátku pouze na základě terénního průzkumu. Existence hrdelního soudu, a tedy i popraviště v Přimdě je prokázána i v souvislosti s reformami soudnictví v 60. letech 18. století (Roučka 1957, příloha 1; viz dále). Důvodem absence většího množství písemných zpráv o existenci šibenice a stínadel ze staršího období jsou velmi pravděpodobně opakované požáry obce v průběhu 16. století. Nejstarší matriky včetně úmrtních, v nichž by bylo teoreticky možné dohledat zmínky o vykonaných hrdelních trestech, začínají rokem 1683 (Köferl 1890, 46).

Odkdy však Přimda disponovala hrdelním právem, není zřejmé. Zcela jistě tomu tak bylo před koncem 16. století (Maur 1964, 140). Udělení hrdelního práva však bylo velmi pravděpodobně staršího data a souviselo s rolí Přimdy jako centra panství. Ačkoli hrad je doložen již v průběhu 12. století a kostel sv. Jiří na náměstí je románského původu, městečko se poprvé připomíná až roku 1331, kdy mu Jan Lucemburský udělil některá práva, potvrzovaná i dalšími panovníky (Pelant 1984, 235; Kuča 2004, 224; Durdík 2007, 85-86). Po většinu doby, kdy lze na základě analogií předpokládat vznik zděné šibenice, tedy v 16. století, vlastnili panství s městečkem Švamberkové (Pelant 1984, 235; Kuča 2004, 225). V roce 1675 se Přimda stala součástí panství Nové Dvorce, původně samostatného celku vytvořeného na počátku 17. století z dvorce Přimda vzdáleného 2 km severovýchodně od městečka (Pelant 1984, 235-236; Kuča 2004, 224, 228). Roli soudního centra plnila však nadále Přimda se svým popravištěm.

Soud v Přimdě fungoval jistě do první poloviny 18. století, kdy byl zařazen do soupisu existujících soudů pro účely reformy soudnictví. Ta se uskutečnila roku 1765 a Přimda na základě patentu z 19. srpna 1765 poté patřila mezi soudy, které od 1 . ledna 1766 ztratily hrdelní jurisdikci 
(Roučka 1957, 127). Nadále jim zůstala povinnost spolupracovat při vyšetřování hrdelních zločinů a mít provozuschopné vězení. Současně měly tyto soudy přispívat do tzv. kriminálního fondu pevně stanovenou roční částkou. Kriminální fond sloužil k úhradě nákladů spojených s vykonáváním hrdelní jurisdikce a platů soudních osob. Právě města, jejichž soudům byla hrdelní jurisdikce odňata, byla největším zdrojem př́ijmů kriminálního fondu. Výše př́íspěvků se lišila podle velikosti a zámožnosti měst. Ta byla rozčleněna do čtyř tříd, Přimda se ocitla v nejnižší IV. tř́ídě, a platila tak nejmenší prŕíspěvek $-7 \mathrm{zl} .30 \mathrm{kr}$., později po zvýšení příspěvků 11 zl. ročně (Roučka 1957, 129 a př́iloha č. 1). Zda však soud v Přimdě ještě v době vlastní reformy, tedy v polovině 60 . let 18 . století, skutečně fungoval, není jisté.

Hrdelní pravomoci poté v regionu zůstaly pouze soudu ve Stř́íbře, Plzni a Klatovech, v roce 1783 pak zůstaly pouze soudům v Plzni a Klatovech (Roučka 1957, 130), a Tachovsko tak zcela přišlo u svých soudů o hrdelní pravomoci. Reforma se dotkla v okolí ještě soudů v Stráži, Boru (tyto soudy byly zařazeny do II. trrídy), Tachově (zařazen do III. trrídy) a ve Starém Sedlišti (stejně jako soud v Přimdě i tento byl zařazen do IV. třídy; Roučka 1957, př́íloha č. 1).

\section{Historie výzkumu}

Relikty šibenice u Přimdy v okrese Tachov byly objeveny při průzkumu lokality v roce 2006 (obr. 6). V roce 2007 došlo k základní dokumentaci objevených reliktů a k ověření jejich charakteru. Drobná sondáž formou odstranění lesní půdy napříč severní částí prstencového valu tehdy odkryla povrch kamenné sutě ze zdiva tvořeného lomovým kamenem zděným na vápennou maltu. Interpretaci nalezeného objektu jako historické šibenice potvrdily i ojedinělé údaje z literatury, zmiňující existenci zbytků šibenice koncem 19. století i existenci hrdelního práva a soudu v Přimdě do poloviny 18. století. Přimdecká šibenice je tedy jedním z mála takových objektů, které se v České republice do současnosti dochovaly ve formě reliktů patrných v terénu. V roce 2011 byly publikovány základní informace o lokalitě, zasazení do historického kontextu i bádání o těchto raně novověkých typech objektů (Sokol 2011). Během října 2014 se pak uskutečnil

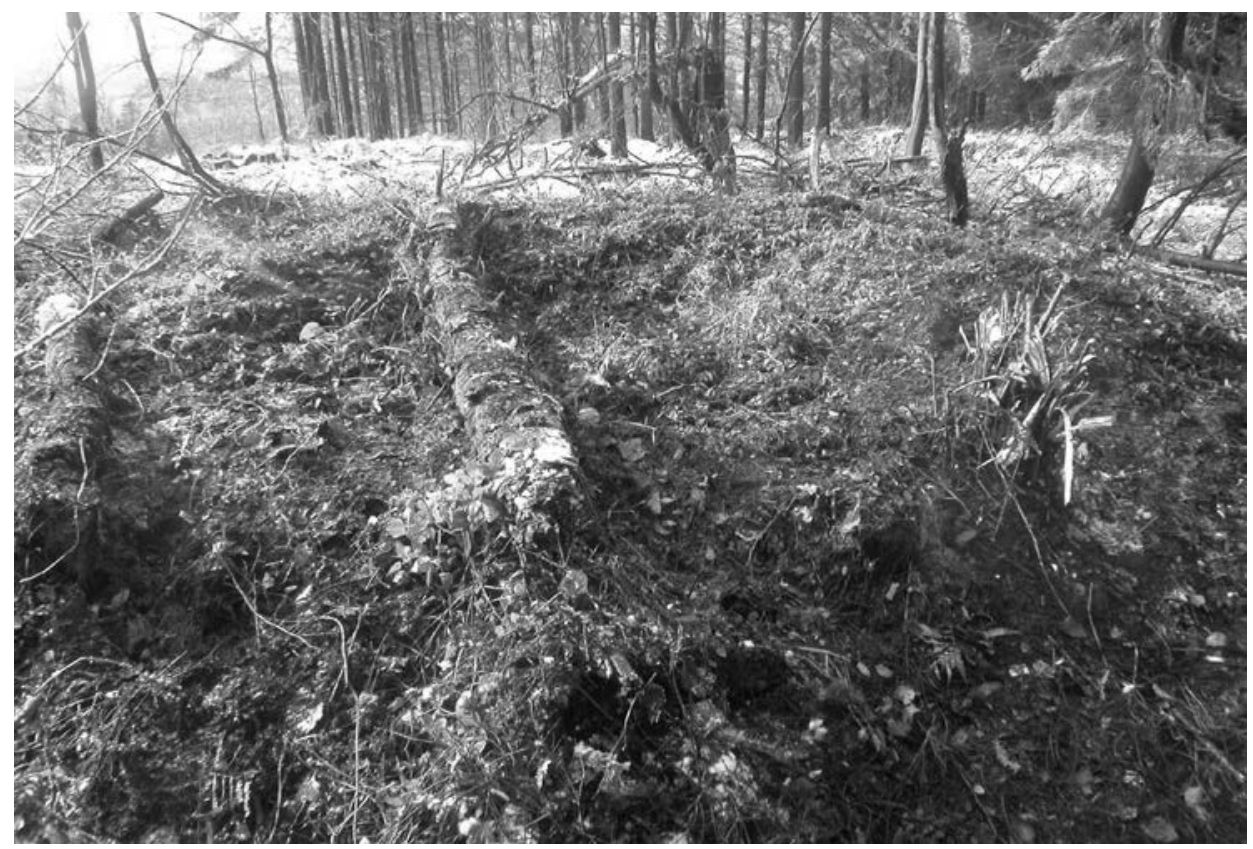

Obr. 6. Přimda, okr. Tachov. Relikty šibenice od severovýchodu v roce 2007. Foto P. Sokol.

Abb. 6. Přimda, Bezirk Tachov. Blick von Nordosten auf die Galgenrelikte im Jahr 2007. Foto P. Sokol. 
výzkum objektu formou několika sond za účelem získání základních poznatků o míře zachování reliktu, vzhledu stavby, stratigrafii a nálezovém potenciálu lokality v návaznosti na záměr města toto místo turisticky zpřístupnit (Sokol 2015).

\section{Výzkum v roce 2014}

Terénní část výzkumu, kterou provádělo plzeňské pracoviště NPÚ ve spolupráci s Muzeem Českého lesa v Tachově, měla podobu šesti sond rozmístěných uvnitř i vně přibližně kruhového reliktu z kamene zděné stavby, jehož zdivo vystupovalo mírně nad terén a bylo překryto kamennou sutí. Ta byla zájemci o lokalitu před zahájením výzkumu vysbírána z povrchu terénu a zčásti navršena na korunu reliktu, čímž došlo k jeho překrytí a zkreslení vzhledu. Vzhledem k množství kamenů a záměru prezentovat lokalitu veřejnosti byla tato vyrovnávka na reliktu zdiva ponechána jako ochranná vrstva v průběhu výzkumu i pro zvýraznění půdorysu šibenice při následné prezentaci. Rozmístění sond bylo zvoleno tak, aby byly pokryty všechny strany exteriéru v návaznosti na zdivo, vstup do objektu, patrný snížením koruny valu, a interiér objektu (obr. 7 a 8). Cílem takovéhoto rozmístění sond bylo získat základní informace o skladbě terénu kolem šibenice a v jejím interiéru. Současně bylo možné předpokládat i zachycení jednotlivých hrobů. Původně zamýšlený geofyzikální průzkum okolí šibenice s cílem detekovat př́ípadné hroby se pro nerovný terén a vegetaci neuskutečnil. Z časových a klimatických důvodů neproběhla ani plánovaná sondáž v odstupu od šibenice rovněž s cílem zachytit př́ípadné hroby.

Sondy byly vyhloubeny na úroveň podloží, na několika místech pod úroveň základové spáry, zasahující do podloží. V průběhu odkryvu byla prováděna detekce kovových předmětů v sondách i na hromadách vytěžené zeminy (N. Rayman, Muzeum Českého lesa v Tachově), jejímž výsledkem bylo zachycení drobných kovových předmětů, které by jinak velmi pravděpodobně unikly pozornosti. Objekt i sondy byly geodeticky zaměřeny, ve spolupráci s NPÚ ÚOP v Lokti (F. Prekop) byla provedena fotogrammetrická dokumentace a vytvořen georeferencovaný fotoplán (obr. 8) i 3D model. Celá situace byla po dokončení terénních prací zdokumentována lase-

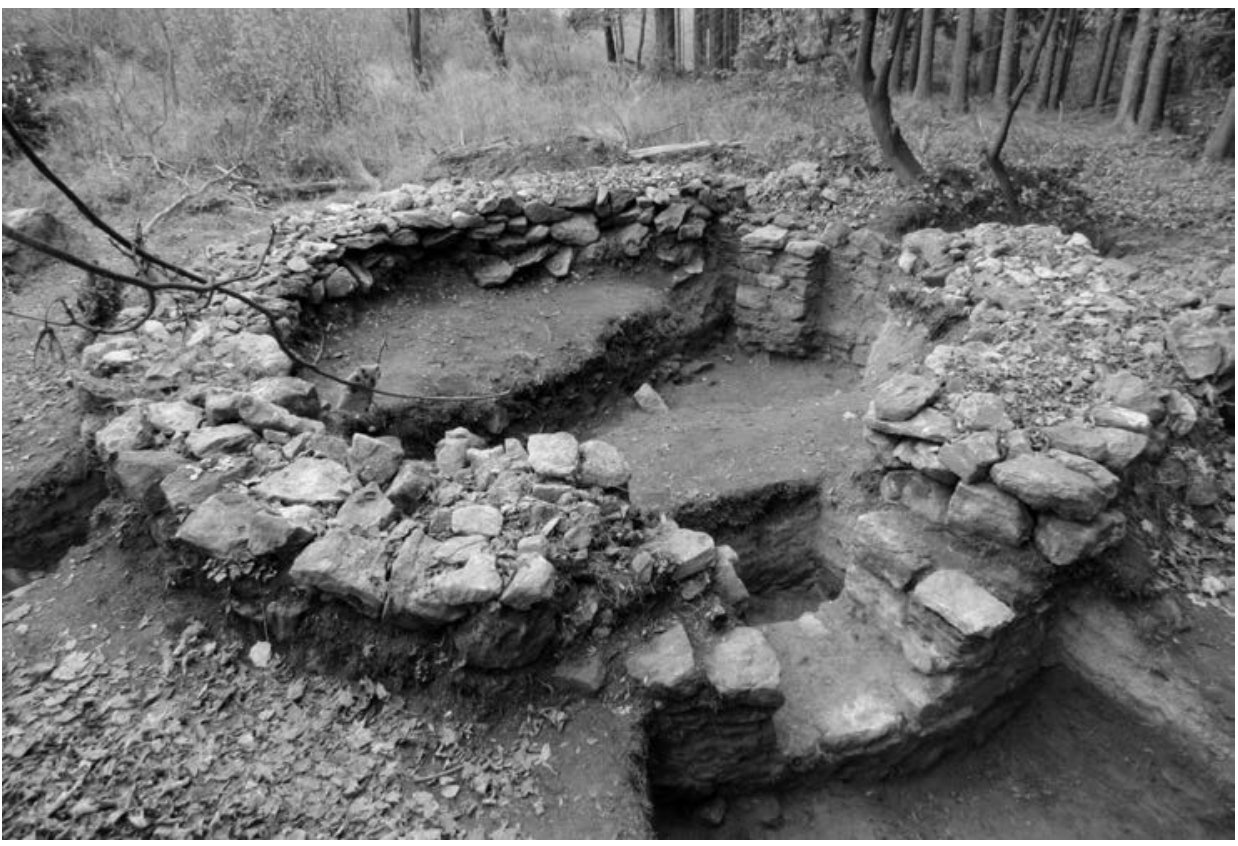

Obr. 7. Přimda, okr. Tachov. Celkový pohled na relikty šibenice od severovýchodu po ukončení výzkumu v roce 2014. Foto P. Sokol. Abb. 7. Přimda, Bezirk Tachov. Gesamtansicht der Galgenrelikte aus Nordosten nach Grabungsende im Jahr 2014. Foto P. Sokol. 
rovým skenováním (M. Kudrnovský), na jehož základě vznikl netexturovaný 3D model lokality. Kovové nálezy prošly konzervací (V. Dudková, ZČM v Plzni), kosterní materiál antropologickou analýzou (J. Šneberger), vzorky malty byly analyzovány v technologické laboratoři NPÚ generálního ředitelství v Praze (J. Kuneš).

\section{Popis terénní situace}

Sonda I (obr. 9) o rozměrech $1 \times 4,3$ m byla umístěna na severozápadní straně šibenice. Ze svrchní sutě při zdivu byly získány dva zlomky keramiky. Pod lesní půdou byly do vzdálenosti $1 \mathrm{~m}$ od zdiva slabé sut'ové vrstvy o celkové výšce ca $50 \mathrm{~cm}$ u zdiva. Těchto několik vrstev s obsahem vápna a písku se vzájemně lišily i obsahem půdní složky, přičemž se střídaly světlejší $\mathrm{s}$ tmavšími. Sutové vrstvy nasedaly v hloubce $90 \mathrm{~cm}$ na úroveň tehdejšího terénu, pod níž se v hloubce $105 \mathrm{~cm}$ nacházelo podloží.

Sonda II o rozměrech $2 \times 2$ m byla umístěna uvnitř šibenice tak, aby do sebe zahrnula amatérský výkop, který odhalil část západního pilíře vystupujícího z obvodového zdiva (obr. 10). Úroveň povrchu terénu zde byla vůči okolí snížena. V mocné svrchní sutové vrstvě byl nalezen kovaný železný hřebík. Pochází z ní i část lebeční kosti a část železné lžíce (bez rukojeti). Úroveň podloží se zde nacházela v hloubce $1,2 \mathrm{~m}$ u zdiva, $0,5 \mathrm{~m}$ na východním konci sondy. Z jeho povrchu pochází nález zlomku keramiky. Nad podložím vznikla vrstva, jejíž horní úroveň představovala zřejmě finální povrch tehdejšího terénu v šibenici. Koncentrace menších kamenů uložených v této vrstvě v hloubce ca $30 \mathrm{~cm}$ v severovýchodním koutu sondy naznačuje možnost hrubé úpravy povrchu. Na tehdejší terén nasedaly od zdiva sutové vrstvy, klínovitě navyšující mírně se ke zdivu svažující terén (obr. 11 a 12). V těchto sutových vrstvách byla nalezena lidská kost. Svrchní, nejmohutnější vrstva sutě, kterou lze spojit s konečnou destrukcí objektu, pře-

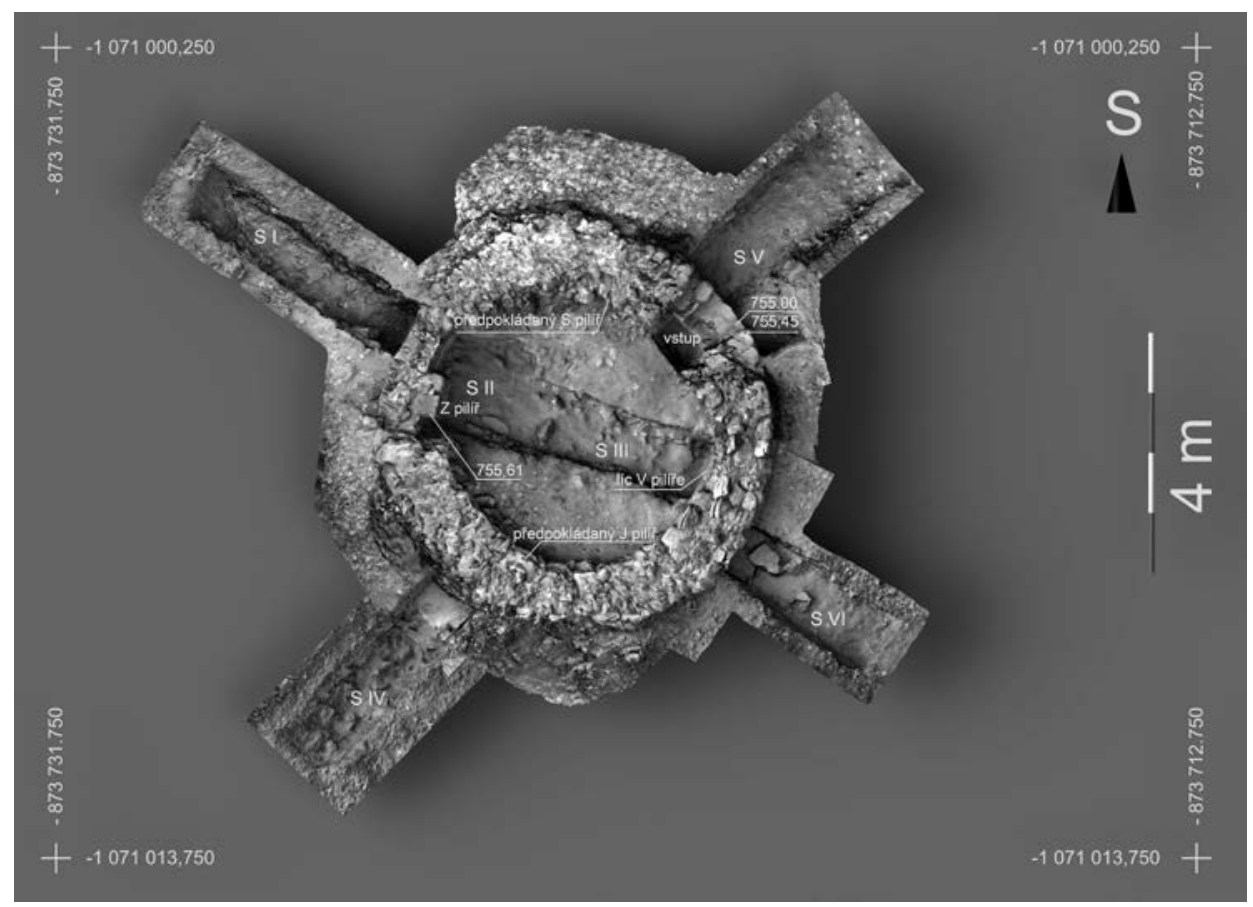

Obr. 8. Přimda, okr. Tachov. Georeferencovaný fotoplán reliktů šibenice a archeologických sond. Zpracovali F. Prekop a P. Sokol, 2014.

Abb. 8. Přimda, Bezirk Tachov. Georeferenzierter Fotoplan der Galgenrelikte und archäologischer Sondierungsgrabungen. Erstellt von F. Prekop und P. Sokol, 2014. 
krývala tuto situaci v celé ploše interiéru šibenice. V jižním profilu se projevil $40 \mathrm{~cm}$ hluboký recentní zásah v podobě jámy vyplněné lesní sypkou půdou s kořeny a kameny, která zaujímala značnou část interiéru, pravděpodobně starší vývrat stromu. Odkrytý západní pilíř byl provázán s navazujícím obvodovým zdivem, při jehož začištování vnitřního líce byl nalezen krční obratel.

Sonda III byla pokračováním sondy II v šiřrce $1 \mathrm{~m}$ směrem k východu, kde byl podle předpokladu odkryt druhý pilíř situovaný proti pilíři západnímu. Z možností tř́i nebo čtyř pilírưu, vyskytujících se u kruhových typů šibenic, byla tedy potvrzena možnost druhá - čtyři pilíře,

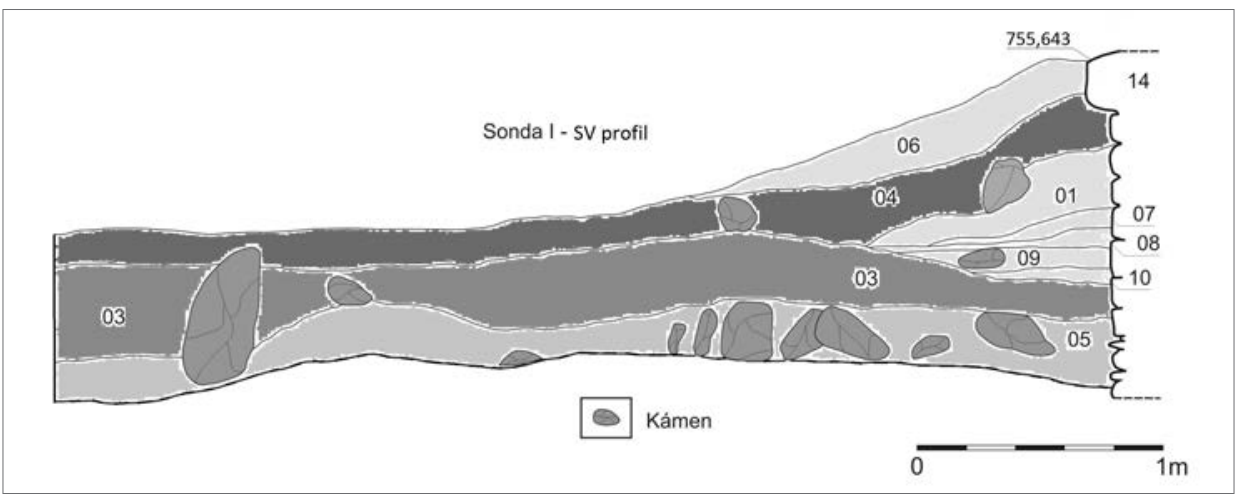

Obr. 9. Přimda, okr. Tachov. Sonda I, severní profil. Vrstvy 01, 06-10 - destrukce; 03 - historický terén; 04 - lesní půda; 05 - podloží; 14 - zdivo. Kresba P. Sokol a L. Hobl.

Abb. 9. Přimda, Bezirk Tachov. Sondierungsgrabung I, Nordprofil. Schichten 01, 06-10 - Zerstörungsschicht; 03 - historisches Gelände; 04 - Waldboden; 05 - Untergrund; 14 - Mauerwerk. Zeichnung P. Sokol und L. Hobl.

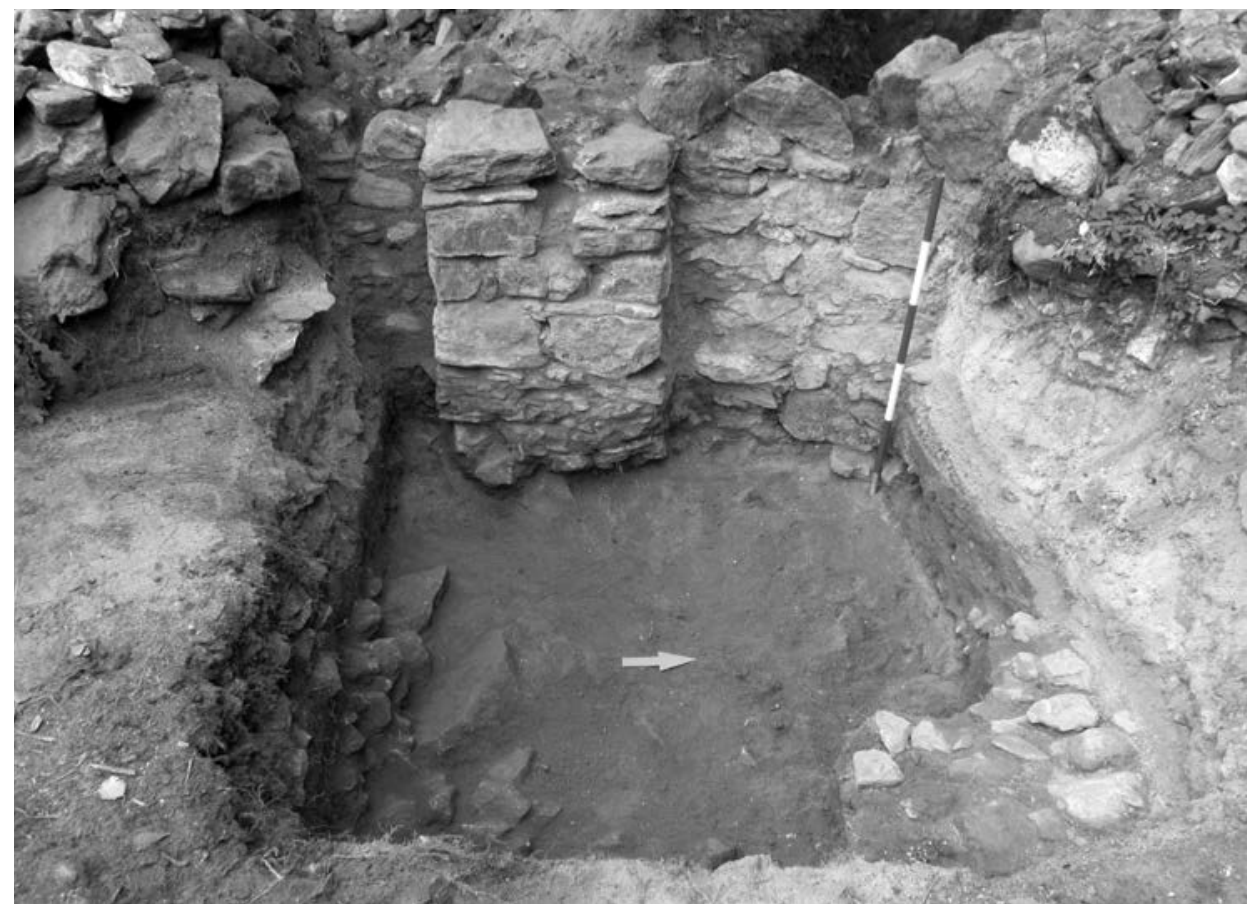

Obr. 10. Přimda, okr. Tachov. Sonda II, pohled od východu. Západní pilíŕ vystupující z obvodového zdiva. Foto P. Sokol, 2014. Abb. 10. Přimda, Bezirk Tachov. Sondierungsgrabung II, Blick von Osten. Aus der Außenmauer hervortretender Westpfeiler. Foto P. Sokol, 2014. 
v tomto př́ípadě vystupující na vnitřní straně z obvodového zdiva již od úrovně základové spáry. Východní pilíř předstupoval před obvodovou zed' o $40 \mathrm{~cm}$. Líc pilíře byl rozvolněný s většími spárami, kameny vystupovaly nejen před přední linii základu, ale i do stran. Situace v sondě III (obr. 13-15) odpovídala zjištěním v sondě II. V sut'ové vrstvě pod lesní půdou bylo v hloubce $40 \mathrm{~cm}$ nalezeno lidské žebro. V hloubce ca $80 \mathrm{~cm}$ od vrcholku pilíře na úrovni historického terénu se v ploše projevovala koncentrace kamenů, obdobně jako v severovýchodním koutu sondy II, zde navíc s drobnými uhlíky. Záměrné uložení kamenů však nebylo jednoznačně prokázáno,

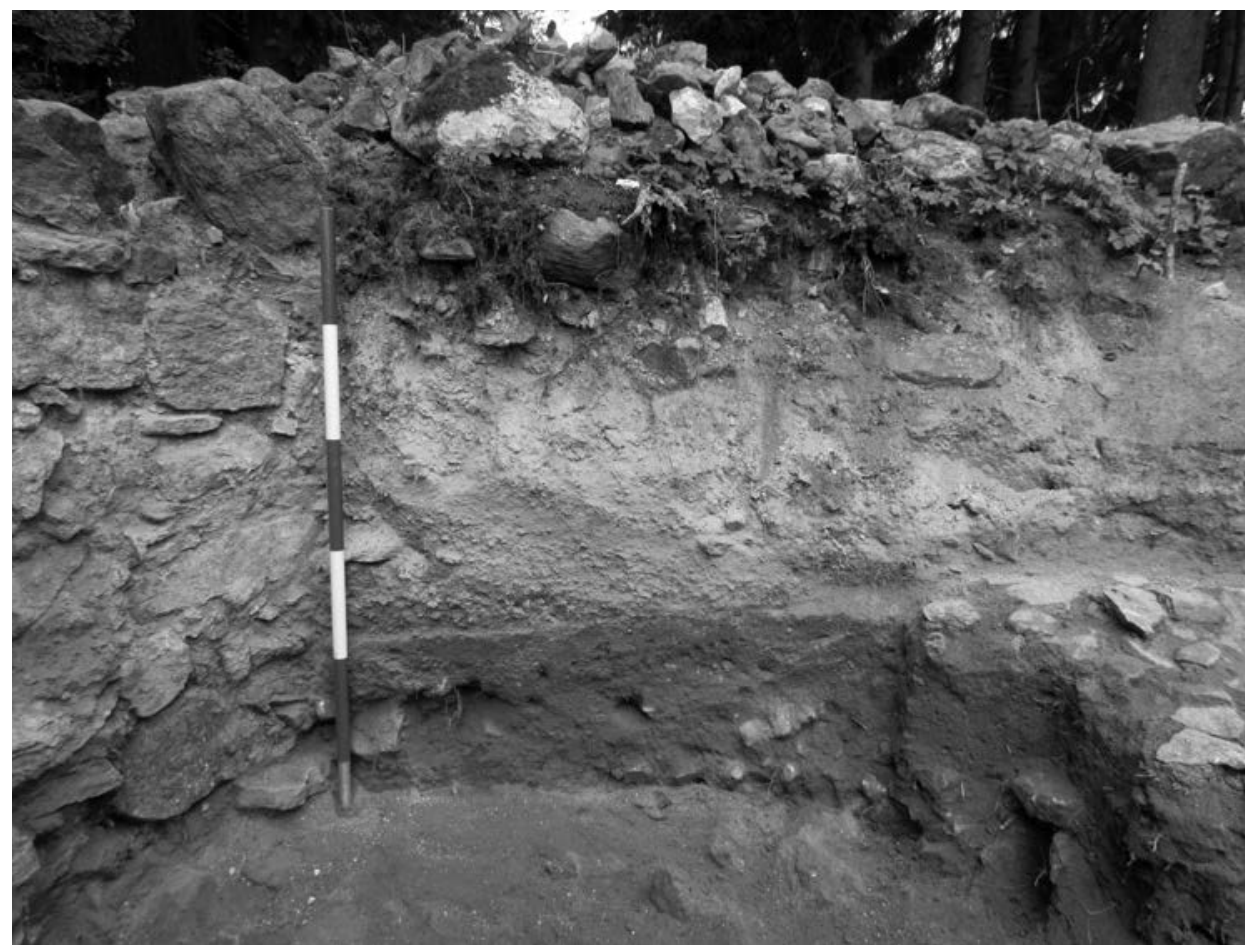

Obr. 11. Přimda, okr. Tachov. Sonda II, severní profil. Foto P. Sokol, 2014.

Abb. 11. Přimda, Bezirk Tachov. Sondierungsgrabung II, Nordprofil. Foto P. Sokol, 2014.

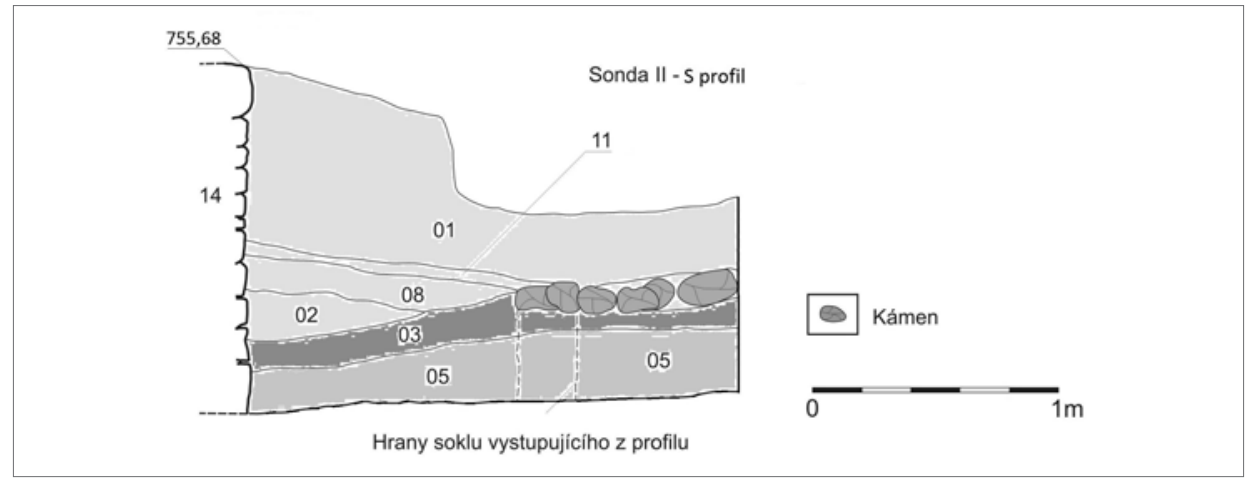

Obr. 12. Přimda, okr. Tachov. Sonda II, severní profil. Vrstvy 01, 02, 08, 11 - destrukce; 03 - historický terén; 05 - podloží; 14 - zdivo. Kresba P. Sokol a L. Hobl.

Abb. 12. Přimda, Bezirk Tachov. Sondierungsgrabung II, Nordprofil. Schichten 01, 02, 08, 11 - Zerstörungsschicht; 03 historisches Gelände; 05 - Untergrund; 14 - Mauerwerk. Zeichnung P. Sokol und L. Hobl. 
kameny byly směřovány vzhůru i svými hranami. Při západním okraji sondy byla na úrovni historického terénu nalezena kumulace drobných keramických střípků pocházejících z jedné nádobky (hrnečku) a zlomky lidských kostí.

Sonda IV o rozměrech $1,2 \times 3,6$ m byla umístěna k jihozápadní straně objektu proti vstupu do šibenice. Skladbu vrstev tvořil do vzdálenosti $60 \mathrm{~cm}$ od zdiva úsek sutových vrstev, ve zbylé ploše sondy jen lesní půda a pod ní se nad podložím nacházející až $40 \mathrm{~cm}$ mocná vrstva. Její

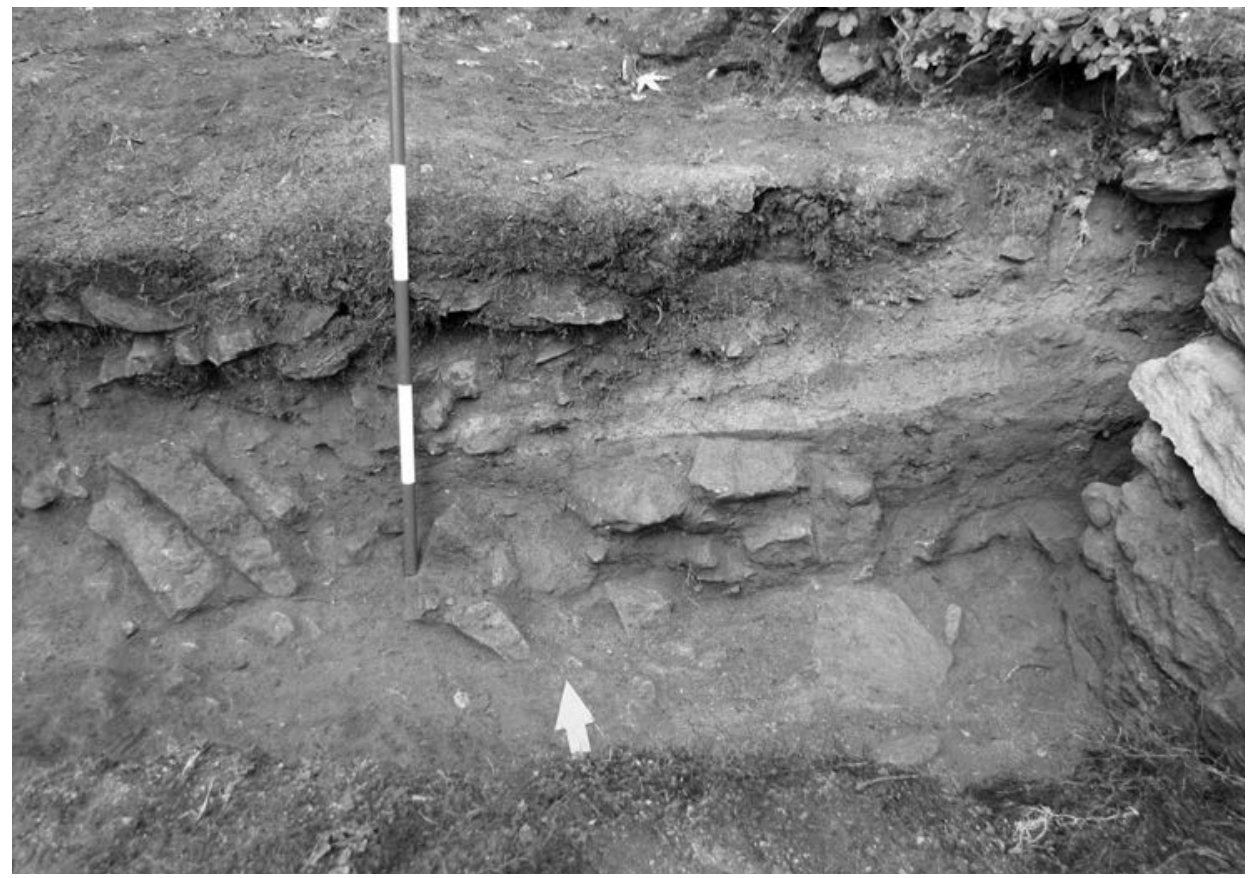

Obr. 13. Přimda, okr. Tachov. Sonda III, severní profil. Foto P. Sokol, 2014.

Abb. 13. Přimda, Bezirk Tachov. Sondierungsgrabung III, Nordprofil. Foto P. Sokol, 2014.

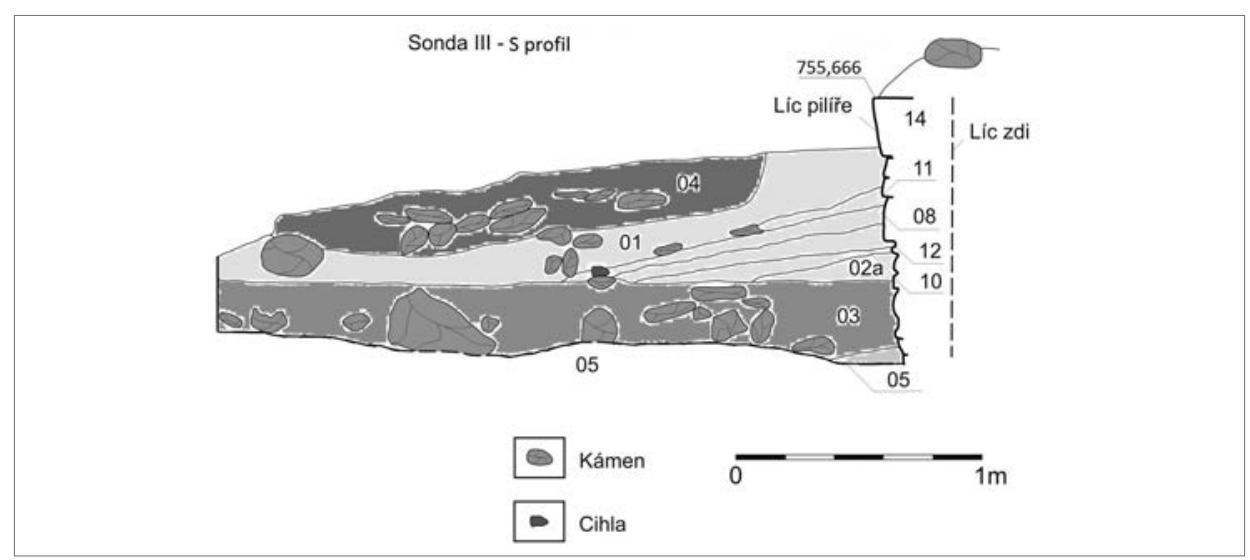

Obr. 14. Přimda, okr. Tachov. Sonda III, severní profil. Vrstvy 01, 02a, 08, 10-12 - destrukce; 03 - historický terén; 04 - lesní půda (výplň vývratu); 05 - podloží; 14 -zdivo. Kresba P. Sokol a L. Hobl.

Abb. 14. Přimda, Bezirk Tachov. Sondierungsgrabung III, Nordprofil. Schichten 01, 02a, 08, 10-12 - Zerstörungsschicht; 03 - historisches Gelände; 04 - Waldboden (Baumbruchverfüllung); 05 - Untergrund; 14 - Mauerwerk. Zeichnung P. Sokol und L. Hobl. 


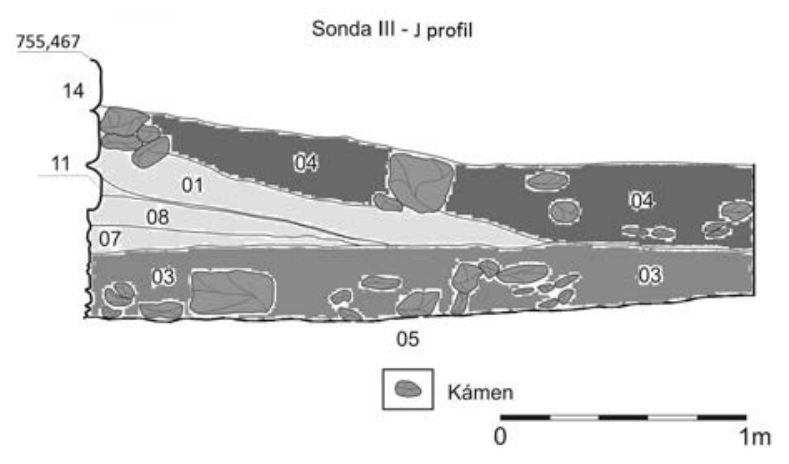

Obr. 15. Přimda, okr. Tachov. Sonda III, jižní profil. Vrstvy 01, 07, 08, 11 - destrukce; 03 - historický terén; 04 - lesní půda; 05 - podloží; 14 - zdivo. Kresba P. Sokol a L. Hobl.

Abb. 15. Přimda, Bezirk Tachov. Sondierungsgrabung III, Südprofil. Schichten 01, 07, 08, 11 - Zerstörungsschicht; 03 - historisches Gelände; 04 - Waldboden; 05 - Untergrund; 14 - Mauerwerk. Zeichnung P. Sokol und L. Hobl.

horní úroveň představuje finální povrch historického terénu. Pomocí detektoru byly při průzkumu zeminy ze sond III a IV získány části šatního spínadla - očko k háčku a část druhého očka.

Původní rozměry sondy $\mathrm{V}$ umístěné $\mathrm{k}$ severovýchodní straně do míst předpokládaného vstupu byly $1,5 \times 4 \mathrm{~m}$. Stratigrafie zde byla obdobná předchozím zjištěním: pod vrstvou lesní půdy se nacházelo několik slabších vrstev vzniklých v důsledku eroze zdiva (pojiva), které se směrem od objektu vytrácely. Pod nimi byla již vrstva historického terénu nasedající na podloží. To bylo zřejmě pří zakládání šibenice upraveno dílčím odkopáním, takže se z vnější strany mírně svažovalo směrem ke zdivu. Před vstupem do šibenice byly ve vrstvě vytvářející historický terén nalezeny pomocí detektoru další šatní spínadla: háček a knoflík s ouškem. Opět z úrovně historického povrchu terénu pochází skupinka střepů z jedné nádoby. Ze sondy byly získány zlomky železných hřebíků, keramiky a lidských kostí. Sonda byla následně rozšířena tak, aby byl odkryt vstup do šibenice v celé šiřce, včetně vnitřního prostoru šibenice za vstupem (obr. 16), kde byl nalezen mj. lidský bederní obratel. Vnější šířka vstupu byla $77 \mathrm{~cm}$, vnitřní $57 \mathrm{~cm}$. Tloušt'ka obvodového zdiva zde dosahovala $70 \mathrm{~cm}$. Výška prahu nad základovou spárou byla $45 \mathrm{~cm}$, nad úrovní historického terénu $15 \mathrm{~cm}$. Dochovaná výška zbytku vstupního otvoru byla $45 \mathrm{~cm}$ (obr. 17). Pochozí plocha vstupu byla vyzděna z běžných kamenů a vyrovnána maltou, nebyly zachyceny stopy osazení dveří. Z vnější strany zdiva byla část podloží nejspíše odkopáním při zakládání stavby snížena až na úroveň základové spáry, podobně jako v sondách I a II (obr. 18). Obdobné snížení, ovšem výraznější, lze pozorovat i u vrstvy, jejíž povrch představuje finální úroveň historického terénu. Toto snížení v blízkosti objektu v porovnání se vzdálenější částí sondy je možné hodnotit snad jako důsledek záměrného udržování úrovně terénu v prostoru před vstupem do šibenice, vyloučit však nelze ani existenci nevýrazného a značně širokého základového vkopu (z vnější strany ca 1,5 m). Movité nálezy pochází z vrstvy historického terénu, $\mathrm{z}$ destrukčních vrstev i z předělu těchto dvou úrovní.

Sonda VI o rozměrech $1 \times 3 \mathrm{~m}$ byla umístěna $\mathrm{k}$ jihovýchodní straně objektu, proti sondě I (obr. 19). Ani zde se stratigrafická situace nelišila od předchozích sond (obr. 20). Sut'ové vrstvy $\mathrm{s}$ vysokým obsahem vápna sahaly do vzdálenosti $1,5 \mathrm{~m}$ od zdiva. Obsahovaly železný hřebík, část dalšího, část špendlíku, deformovanou olověnou kuli a zlomky cihel. Z hlinité vrstvy představující úroveň historického terénu byla získána část lebeční kosti.

\section{Objekt šibenice}

Před vlastní stavbou bylo hlinito-jílovité podloží s množstvím kamenů mírně zarovnáno, v některých místech se jeví náznak mělkého a širokého základového vkopu. Zdivo bylo založeno do podloží mělce, $10-25 \mathrm{~cm}$, na jihozápadní straně v této hloubce vystupovalo již skalní podloží. 


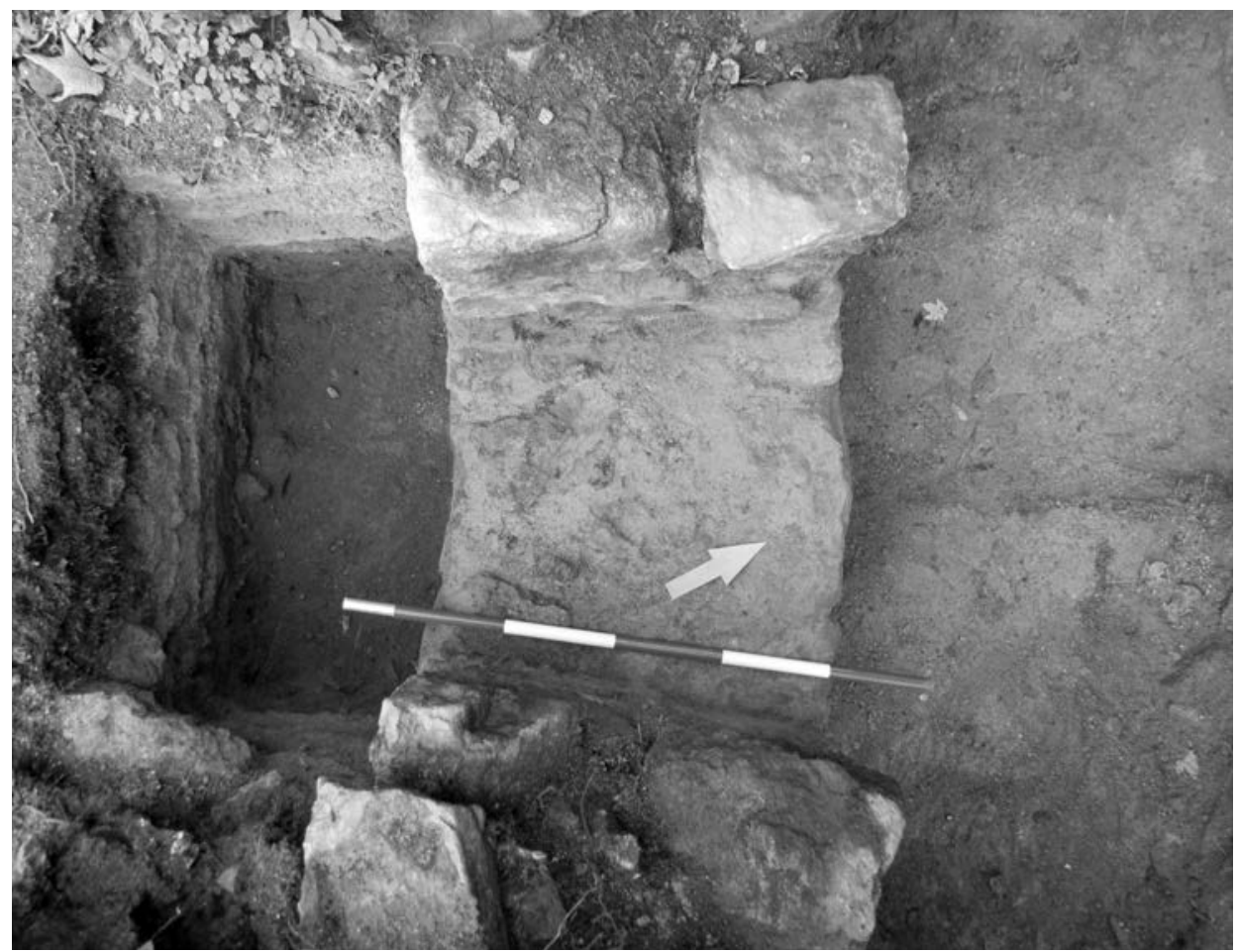

Obr. 16. Přimda, okr. Tachov. Sonda V - dochovaná spodní část vstupu do šibenice. Foto P. Sokol, 2014.

Abb. 16. Přimda, Bezirk Tachov. Sondierungsgrabung V-erhaltener unterer Teil des Eingangs zum Galgen. Foto P. Sokol, 2014.

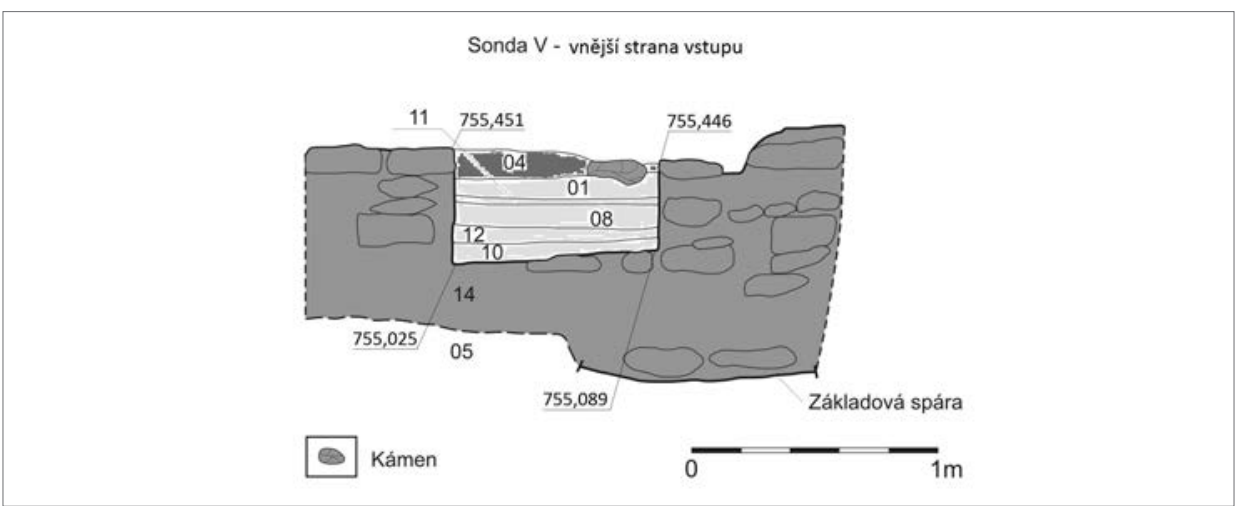

Obr. 17. Přimda, okr. Tachov. Sonda V - vstup do šibenice. Vrstvy 01, 08, 10-12 - destrukce; 04 - lesní půda; 05 - podloží; 14 -zdivo. Kresba P. Sokol a L. Hobl.

Abb. 17. Přimda, Bezirk Tachov. Sondierungsgrabung V - Eingang zum Galgen. Schichten 01, 08, 10-12 - Zerstörungsschicht; 04 - Waldboden; 05 - Untergrund; 14 - Mauerwerk. Zeichnung P. Sokol und L. Hobl.

Šibenice byla nepravidelného kruhového půdorysu o vnějším průměru ca 6,2 m při tloušt'ce zdiva pohybující se mezi 0,63 a $0,72 \mathrm{~m}$. Zdivo šibenice je zachováno do výšky přibližně $1 \mathrm{~m}$ od základové spáry. Stavba byla zděná z lomového kamene na maltu a zřejmě zevnitř i zvenku omítnuta a opatřena vápenným nátěrem. Úlomky malty ze sutě i ze zachovalého zdiva byly analyzovány v technologické laboratoři generálního ředitelství NPÚ v Praze za účelem detekce výskytu úprav a jejich typu pomocí stratigrafické analýzy a charakteristiky vzorků a jejich vzájemného srovnání. 


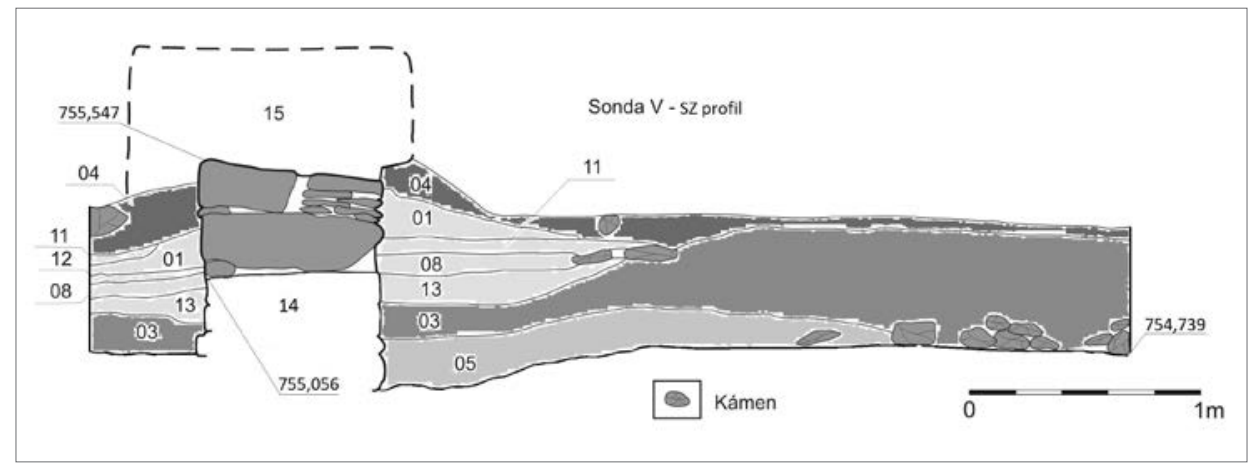

Obr. 18. Přimda, okr. Tachov. Sonda V - vstup do šibenice, severozápadní profil. Vrstvy 01, 08, 11-13 - destrukce; 03 - historický terén; 04 - lesní půda; 05 - podloží; 14 - zdivo; 15 - recentní kamenná rovnanina ze sutě. Kresba P. Sokol a L. Hobl. Abb. 18. Přrimda, Bezirk Tachov. Sondierungsgrabung V - Eingang zum Galgen, Nordwestprofil. Schichten 01, 08, 11-13 Zerstörungsschicht; 03 - historisches Gelände; 04 - Waldboden; 05 - Untergrund; 14 - Mauerwerk; 15 - rezente Steinschlichtung Blockschutt. Zeichnung P. Sokol und L. Hobl.

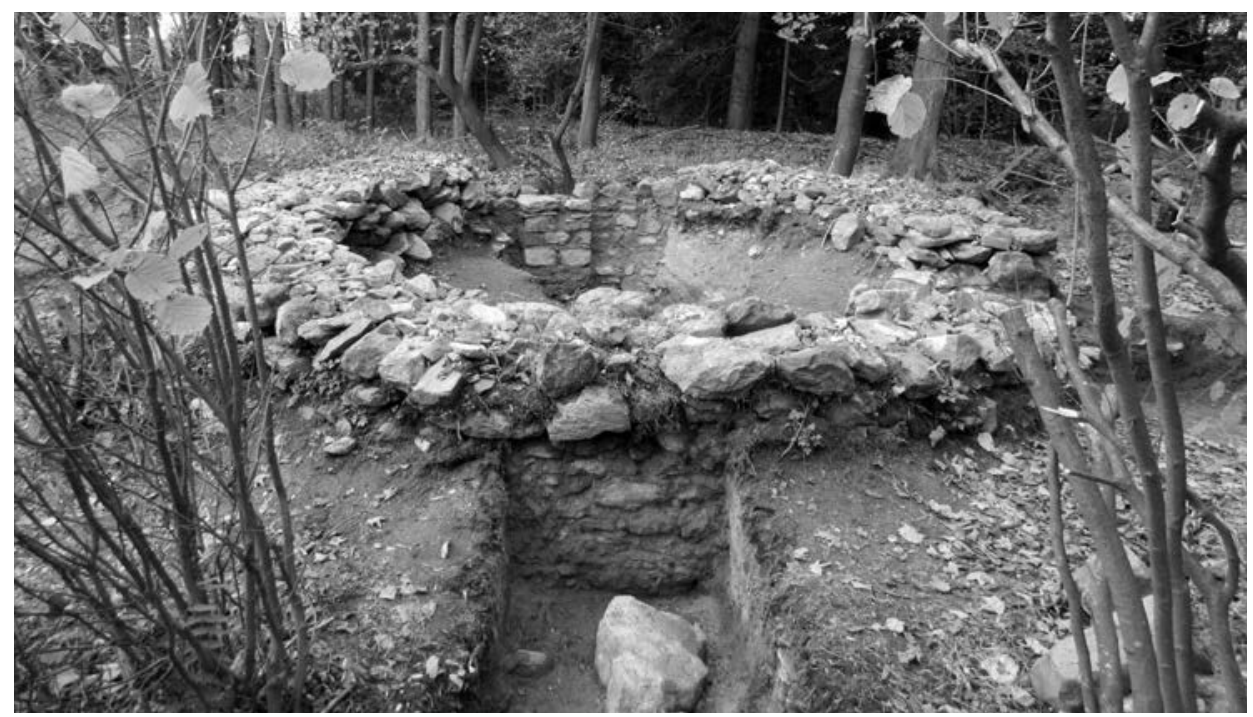

Obr. 19. Přrimda, okr. Tachov. Sonda VI, pohled od jihovýchodu. Foto P. Sokol, 2014.

Abb. 19. Přimda, Bezirk Tachov. Sondierungsgrabung VI, Blick von Südosten. Foto P. Sokol, 2014.

Analyzované vzorky (sut', zdivo) se významně lišily charakterem kameniva (rozměry, mineralogicky), což nelze vysvětlit pouze variabilitou surovin při př́ipravě malt. Vzorky tak představují doklady minimálně dvou různých etap zdění, tedy pravděpodobně opravu objektu, která z písemných pramenů není známa. Povrchová úprava jednoho z analyzovaných vzorků spočívala v silném vápenném nátěru smetanové barvy, který byl aplikován bezprostředně po nanesení malty na zdivo (Kuneš 2015).

Ačkoli v odkrytých úsecích zdiva cihly prokázány nebyly, zlomky cihel ukazují na občasné využití i tohoto materiálu. Nepatrné množství těchto zlomků nás vede k závěru, že cihly byly použity zřejmě jen pro některé detaily stavby (např. vyzdění koruny obvodové zdi nebo pilírů či zaklenutí vstupního otvoru) nebo jako nepočetná příměs či vysprávky jinak kamenného zdiva. Na čtyřech pilíŕích vystupujících z obvodového zdiva do interiéru byla v původně několikametrové výšce upevněna dřevěná břevna. Do šibenice se vstupovalo na severovýchodní straně vstupem o šířce 0,75 m, zbytky konstrukce dveří, které zde nutně musely být, se nepodařilo výzkumem doložit. 


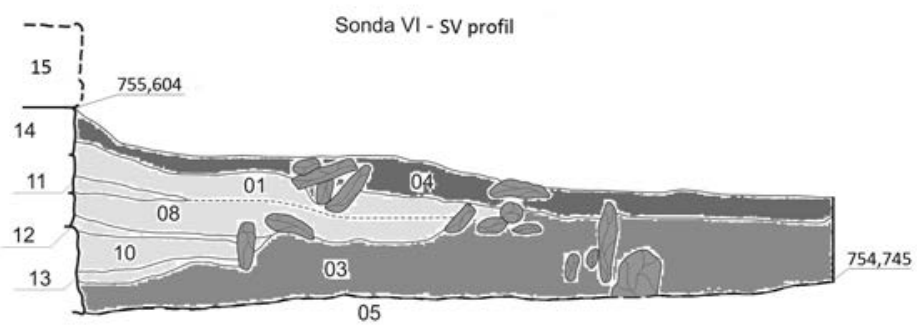

Kámen

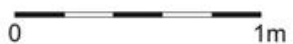

Obr. 20. Přimda, okr. Tachov. Sonda VI, severovýchodní profil. Vrstvy 01, 08, 10-13 - destrukce; 03 - historický terén; 04 lesní půda; 05 - podloží; 14 - zdivo; 15 - recentní kamenná rovnanina ze sutě. Kresba P. Sokol a L. Hobl.

Abb. 20. Přimda, Bezirk Tachov. Sondierungsgrabung VI, Nordostprofil. Schichten 01, 08, 10-13 - Zerstörungsschicht; 03 historisches Gelände; 04 - Waldboden; 05 - Untergrund; 14 - Mauerwerk; 15 - rezente Steinschlichtung aus Blockschutt. Zeichnung P. Sokol und L. Hobl.

Přimdecká šibenice byla tedy jednou z obdobných staveb kruhového půdorysu, které se v Čechách v průběhu raného novověku budovaly zejména v západní a severní části Čech a ve Slezsku (Sokol 2008, 261-262; 2010, 361), potažmo v severní části střední Evropy vůbec, patřily však zřejmě na území Čech - ve srovnání s objekty pravoúhlého půdorysu - k méně početným. V reliktech dochovaných šibenic s kruhovým půdorysem jde ze západočeských o Horní Slavkov a Bečov nad Teplou (viz Sokol 2003, zvl. 751n; 2003a; 2008), ze severní části Čech pak jmenujme Ústí nad Labem, Železný Brod, z historických vyobrazení je známá např. šibenice v Jaroměři, Kadani, Lounech či Náchodě. Z Dolního Slezska lze uvést z částečně dochovaných či archeologicky zkoumaných např. lokality Jelenia Góra, Lipa, Lubań, Miłków, Wojcieszów nebo Złotniky Lubańskie, známých z historických vyobrazení pak např. Niemcza, Nisa, Świdnica, Wołów, Wrocław (Wojtucki 1999; 2009). Pilíŕi předstupujícími již od základu před vnitřní líc obvodové zdi i rozměry se přimdecká šibenice podobá šibenici v dolnoslezské obci Kąty Wrocławskie, která však měla pilíře tři a jejíž zdivo bylo kamenno-cihlové (Nocuń-Paternoga-Tarasiński 1999). U výrazné většiny zděných šibenic s kruhovým půdorysem vyrůstaly pilíře až z koruny obvodové zdi, jakýsi „,negativ“ přimdecké šibenice pak představuje objekt v dolnoslezské lokalitě Mościsko, jehož tř̌i pilíře předstupovaly před vnější líc obvodové zdi (Wojtucki 2009, 522-523).

V průběhu doby fungování přimdecké šibenice došlo k vytvoření úrovně terénu, doložené výskytem movitých nálezů v této vrstvě, na jejím povrchu a ojediněle v interiéru i na rozhraní této vrstvy a podloží. Situace v sondách V a VI naznačuje, že při východní vnější straně objektu mohlo docházet k záměrnému udržování úrovně terénu. Stratigrafie ve všech sondách shodně ukazuje spíše na zánik objektu v několika fázích. Zpočátku, možná ještě před ztrátou funkce objektu, šlo o erozi omítky a pojiva, která se projevila nárůstem vrstviček při zdivu do celkové výšky kolem $40 \mathrm{~cm}$, později došlo k rozsáhlejší destrukci reprezentované mohutnější vrstvou sutě zdiva s kovovými prvky konstrukce (hřebíky) a následnému procesu zániku stavby. Zdivo šibenice podlehlo destrukci téměř až na úroveň terénu. Situaci uvnitř objektu narušil zřrejmě vývrat stromu, jehož jámu vyplnila lesní půda a kamenná sut'.

\section{Lidské pozůstatky}

Z výzkumu pochází 18 jednotlivých kostí, z nichž většina byla nalezena v interiéru šibenice a v prostoru vstupu. Kosti se nacházely jak v úrovni historického terénu, tak i v sut'ových vrstvách. Mezi kostmi nebyla př́tomna ani jedna vhodná pro základní demografické odhady ani pro výpočet minimálního počtu jedinců. Zastoupeny jsou však kosti ze všech částí těla lebky, páteře, hrudníku a končetin. Jde o druhý krční obratel, část levé vřetenní kosti, dva fragmenty jedné lebeční kosti, část pravého žebra, dva fragmenty lícních kostí, sedm drob- 
ných částí zřejmě horní čelisti, část třetího horního metatarsu, čtvrtý levý metacarp, bederní obratel a fragment další lebeční kosti. Na kostech nebyly průkazné známky násilných zásahů, výjimku představuje poškození fragmentu pravého žebra a levého metacarpu, u kterého však nelze vyloučit poškození při exkavaci, a bederního obratle, který nese nejspíše stopy po zubech hlodavce, dokládající alespoň přechodné uložení na povrchu terénu (Šneberger 2014). Všechny získané kosti tedy pochází z těl, která velmi pravděpodobně nebyla pohřbena. Představují doklad ponechání těl na šibenici nebo na povrchu terénu do rozpadu s případným pozdějším mělkým zahrabáním.

\section{Movité nálezy}

Výzkum přinesl i doklady hmotné kultury související s provozem objektu. Nálezy získané při výzkumu pochází z interiéru i exteriéru objektu, vzhledem k poměru prozkoumaných ploch početně převažují nálezy z vnitřního prostoru šibenice, následované nálezy z prostoru před vstupem do objektu. Uloženy byly převážně v úrovni historického terénu i v destrukčních vrstvách.

\section{Keramika}

Nalezené zlomky keramiky $\mathrm{v}$ počtu 177 kusů pochází ze všech šesti sond, a to jak $\mathrm{v}$ úrovni historického terénu, tak $\mathrm{v}$ suti, jen $\mathrm{v}$ jednom př́padě byl střep vyzvednut $\mathrm{z}$ povrchu podloží v interiéru objektu. Nálezy představují fragmenty menších a spíše tenkostěnných nádob, z vnitřní strany glazovaných. Většinu uvedeného počtu tvoří tři koncentrace nadrobno rozdrcených/rozšlapaných menších nádob (hrnečků): jedna na povrchu historického terénu v interiéru (obr. 21), druhá v sutové vrstvě rovněž $\mathrm{v}$ interiéru a třetí na povrchu historického terénu před vstupem do objektu. První a třetí případ potvrzují interpretaci dané vrstvy a dokládají přítomnost odhozených keramických nádob po delší dobu na povrchu terénu. Vzhledem k prostoru nálezu je lze považovat nejspíše za stopy po osobách, které se mohly pohybovat uvnitř šibenice a v její těsné blízkosti, tedy kata a jeho pomocníků, prŕípadně řemeslníků podílejících se na opravě šibenice. Keramiku lze rámcově datovat do 18 . století, s možným přesahem do století předcházejícího.

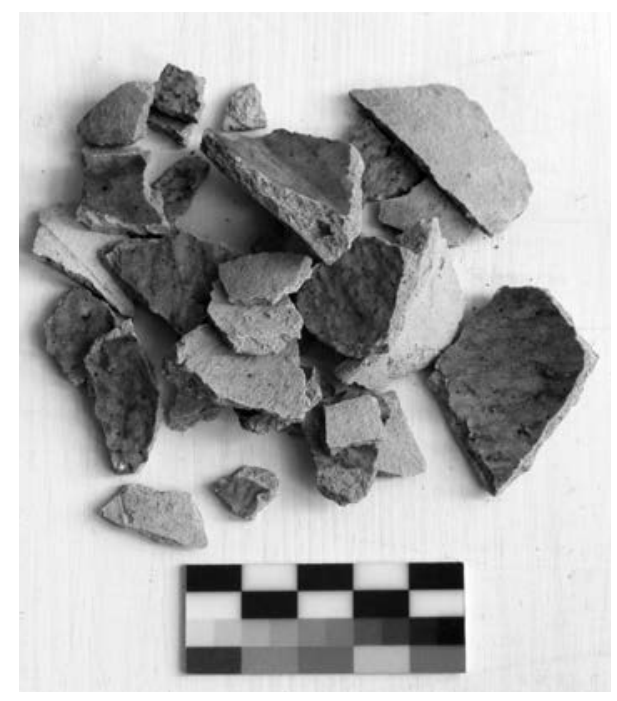

Obr. 21. Přimda, okr. Tachov. Fragmentarizovaná keramická nádobka nalezená na povrchu historického terénu v interiéru šibenice (sonda III). Foto P. Sokol, 2014.

Abb. 21. Přimda, Bezirk Tachov. An der Oberfläche des historischen Geländes im Galgeninnern gefundenes fragmentiertes Keramikgefäß (Sondierungsgrabung III). Foto P. Sokol, 2014.

Kov

Celkem bylo při výzkumu získáno 17 kovových předmětů nebo jejich zlomků, většina z nich pomocí detektoru př̀ hloubení sond. Nálezy kovových předmětů pochází z interiéru i exteriéru objektu, v druhém případě většinou z prostoru před vstupem. Kromě zlomků hřebíků jde o část železné lžíce bez původně přinýtované rukojeti (obr. 22), šatní spínadla (železný háček a 2 očka, knoflík ze slitiny mědi, špendlík - obr. 23 a 24), militaria (nárazem zdeformovaná olověná kule), součásti konstrukce stavby (železné hřebíky a očko - obr. 25) a zlomek železného předmětu nejisté funkce (podkova?). Větší část souboru kovových předmětů tvoří tedy součásti konstrukce šibenice, menší pak šatní spínadla a osobní předměty (lžíce). Stejně jako některé zlomky keramiky i lžíce představuje zřejmě doklad pobytu návštěvníků na šibenici v době jejího zániku. Podobně i kule byla deformována nárazem do zdiva šibenice zřejmě až v době destrukce objektu. 


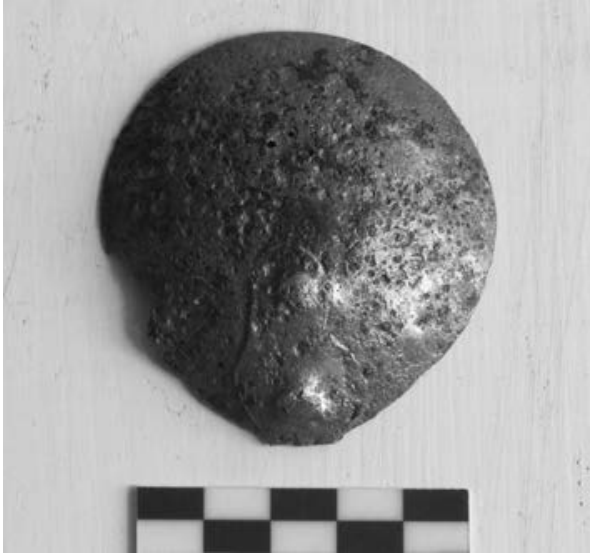

Obr. 22. Přimda, okr. Tachov. Železná lžíce s nýty od rukojeti (sut' v interiéru objektu, sonda II). Foto P. Sokol, 2014. Abb. 22. Přimda, Bezirk Tachov. Eisenlöffel mit Nieten für den Griff (Schutt im Objektinnern, Sondierungsgrabung II). Foto P. Sokol, 2014.

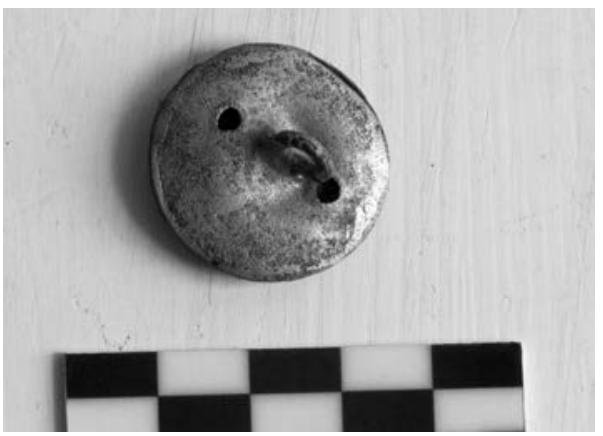

Obr. 24. Přimda, okr. Tachov. Knoflík s poutkem ze slitiny mědi (historický terén před vstupem do šibenice, sonda V). Foto P. Sokol, 2014.

Abb. 24. Přimda, Bezirk Tachov. Knopf mit Öse aus Kupferguss (historisches Gelände vor dem Eingang zum Galgen, Sondierungsgrabung V). Foto P. Sokol, 2014.

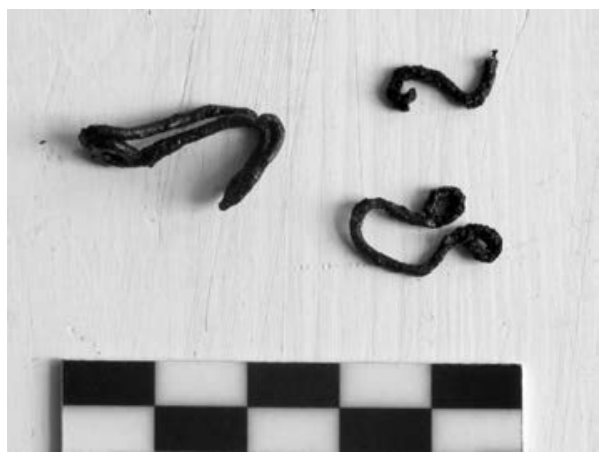

Obr. 23. Přimda, okr. Tachov. Šatní spínadla - železný háček a očka (historický terén před vstupem do šibenice, sonda V). Foto P. Sokol, 2014.

Abb. 23. Přimda, Bezirk Tachov. Kleiderschließen - Eisenhäkchen und Ösen (historisches Gelände vor dem Eingang zum Galgen, Sondierungsgrabung V). Foto P. Sokol, 2014.

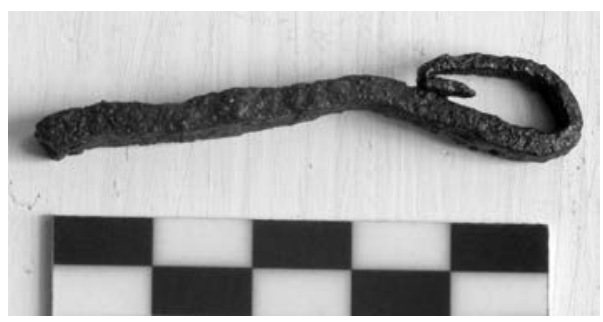

Obr. 25. Přimda, okr. Tachov. Železné očko - součást šibenice? (nad úrovní historického terénu v blízkosti vstupu do šibenice, sonda V). Foto P. Sokol, 2014.

Abb. 25. Přimda, Bezirk Tachov. Eisenöse - Galgenbestandteil? (oberhalb des historischen Geländeniveaus in der Nähe des Eingangs zum Galgen, Sondierungsgrabung V). Foto P. Sokol, 2014.

\section{Datování}

Při datování přimdecké šibenice je možné se opírat jak o získané movité nálezy, tak o písemné zmínky týkajících se výkonu hrdelních trestů v Přimdě. Obojí však poskytuje pouze rámcovou oporu. Nálezy představují běžný raně novověký inventář, který lze řadit snad do 17., jistěji však 18. století. Zatímco oděvní háčky představují běžná šatní spínadla, z méně očekávatelných předmětů v prostředí šibenice jde o lžíci (bez původně přinýtované rukojeti), která zřejmě společně s drobnějšími keramickými nádobami dokládá stravování při pracích na šibenici, a použitá kule, jejíž spojitost s objektem šibenice je spíše náhodná. Ačkoli Přimda disponovala hrdelním právem jistě mnohem dř́ve, z písemných pramenů jsou dosud známy jen zmínky o hrdelních trestech z první poloviny 18. století, přičemž pouze údaj k roku 1726 se týká konkrétně popravy oběšením. Šibenice typu, jaký se uplatnil v Přimdě, byly stavěny v období 16.-18. století. Nálezy i písemné zprávy tak umožňují klást šibenici s jistotou až do 18. století, přičemž zánik hrdelní jurisdikce, a tedy i konec využívání šibenice představuje pro Přimdu, stejně jako v mnoha jiných případech, reforma hrdelního soudnictví v roce 1765. 


\section{Shrnutí}

Jak je již uvedeno výše, šibenice typu, jaký se uplatnil v Přimdě, byly stavěny v období 16.-18. století. Dosud známé zmínky o hrdelních trestech v Přimdě se vztahují jen k první polovině 18 . století, přičemž pouze údaj k roku 1726 se týká konkrétně trestu oběšením, jehož vykonání lze s jistotou spojit s objektem šibenice. Hrdelní právo pro Přimdu je však nutné předpokládat pro mnohem starší období a absenci konkrétních zmínek vztahujících se k jeho uplatnění je třeba považovat za důsledek stavu archivního výzkumu, případně stavu dochování písemných pramenů. Nálezy i písemné zprávy tedy prozatím umožňují klást zkoumanou šibenici s jistotou do 18. století, přičemž zánik hrdelní jurisdikce, a tedy i konec využivání přimdecké šibenice představuje, stejně jako v mnoha jiných případech, reforma hrdelního soudnictví v roce 1765.

Hmotné nálezy získané výzkumem se svou skladbou neliší od jiných výzkumů stejného typu objektu. Jejich menší počet je obecně dán způsobem využití objektu a jeho relativně nízkou frekvencí a nárazovitostí, ale v tomto př́ípadě i nevelkým rozsahem výzkumu. I přesto je však z rozmístění sond a četnosti nálezů zřejmé, že nálezy se koncentrovaly před vstupem do šibenice a v jejím interiéru, tedy zcela v souladu s předpokládaným komunikačním využíváním objektu a jeho nejbližšího okolí. Charakter nalezených předmětů i jejich prostorová distribuce je dovoluje dávat do souvislosti nejpravděpodobněji s osobami katů i odsouzených.

Výzkum šibenice v Přimdě v roce 2014 představuje exkavaci nevelkého rozsahu formou sond za účelem získání základních poznatků o míře zachování reliktu, vzhledu stavby, stratigrafii a nálezovém potenciálu lokality. Archeologický potenciál objektu a jeho nejbližšího okolí není zdaleka vyčerpán, stranou zůstal prostor v okolí šibenice s možným výskytem hrobů, jak to známe z plošných odkryvů tohoto prostorově i společensky specifického typu objektů. Podmínku k plošnému odkryvu okolí přimdecké šibenice však představuje předchozí geofyzikální průzkum za účelem detekce hrobových jam, jehož provedení v dostatečném rozsahu neumožňují místní terénní a vegetační poměry.

\section{Literatura}

DUMA, P., 2010: Grób alienata. Pochówki dzieci nieochrzczonych, samobójców i skazańców w późnym średniowieczu i dobie wczesnonowożytnej. Kraków.

DURDÍK, T., 2007: Hrad Přimda - Die Burg Přimda. Praha.

DÜLMEN, R. van, 2002: Divadlo hrůzy. Praha.

- 2003: Bezectní lidé. O katech, děvkách a mlynářích. Nepočestnost a sociální izolace v raném novověku. Praha.

FRANCEK, J., 1995: Mistři ostrého meče. Pardubice.

FRÖHLICH, J., 2006: Poloha a podoba popravišt' Prácheňského kraje, ASČ 10, 945-957.

- 2008: Přehled popravišt’ Prácheňského kraje. In: Sborník Společnosti pro výzkum kamenných křížů, 110-119. Aš.

KOVÁŘ, D., 2008: Historická popraviště v Bechyňském kraji. In: Sborník Společnosti pro výzkum kamenných kř́ižů, 120-127. Aš.

- 2009: Historická popraviště Bechyňského kraje. Přehled a zhodnocení průzkumu z let 2006-2009, AVJČ 22, 177-256.

- 2010: Pozůstatky historických popravišt’ v jižních Čechách (Chvalšiny a Rožmberk nad Vltavou), Pomniki dawnego prawa 10, 38-45.

KÖFERL, J., 1890: Der politische Bezirk Tachau. Eine Heimatskunde für Haus und Schule unter Mitwirkung der Bezirks-Lehrerschaft. Tachau.

KREUZ, P., 2000: Poprava jako divadlo práva? K otázce právní relevance popravního rituálu v českých městech doby předbělohorské. In: Opera historica 8, 421-457. České Budějovice.

KUČA, K., 2004: Města a městečka v Čechách, na Moravě a ve Slezsku. VI. díl. Praha.

MANSER, J. et al., 1992: Richtstätte und Wasenplatz in Emmenbrücke (16.-19. Jahrhundert): Archäologische und historische Untersuchungen zur geschichte von Strafrechtspflege und Tierhaltung in Luzern. Band I und II. Basel. 
MAŠKOVÁ, P., 2005: K otázce interpretace kostrového pohřebiště „s projevy vampyrismu“v Čelákovicích, Studia Mediaevalia Pragensia 5, 9-19.

- 2010: Dovětek o čelákovickém ,,pohřebišti s projevy vampyrismu“, Středočeský sborník historický 36, 128-133.

- 2015: Faux cimetières. Les lieux d'inhumation des exclus dans les pays de la Couronne de Bohême à l'époque moderne. In: Le cimetière au village dans l'Europe médiévale et moderne (Treffort, C., ed.), 209-220. Toulouse.

MAŠKOVÁ, P.-MICHÁLEK, J., 2006: Archeologický výzkum v poloze „Na šibenici“ ve Vodňanech (okres Strakonice): Př́íspěvek k archeologii popravišt' - Archäologische Grabung in der Flur „Na šibenici“ („Am Galgen“) bei Vodňany (Bezirk Strakonice). Ein Beitrag zur Archäologie der Hinrichtungsstätten in Böhmen, AR LVIII, 790-809.

MAŠKOVÁ, P.-WOJTUCKI, D., 2016: L'archéologie des lieux d'exécution en République Tchèque et en Basse-Silésie (Pologne). In: Criminocorpus. Revue d'Histoire de la justice, des crimes et des peines. Dostupné z http://criminocorpus.revues.org/3115, cit. 17. 2. 2016.

MAUR, E., 1964: Poslední boj přimdeckých Chodů. In: Minulostí Západočeského kraje III, 131-144. Plzeň.

MICHÁLEK, J., 2006: Topograficko-archeologický průzkum a výzkum šibenic v okrese Strakonice v letech 1995-2005, AVJČ 19, 303-323.

NOCUŃ, P.-PATERNOGA, M.-TARASIŃSKI, A., 1999: Szubienica w Kątach Wrocławskich w świetle badań w 1998 roku. In: Śląskie sprawozdania archeologiczne 41, 521-526. Wrocław.

PELANT, J., 1984: Města a městečka Západočeského kraje. Plzeň.

PĚNIČKA, R., 2014: Kostrové nálezy a zacházení s těly zemřelých na šibenici v Tišnově. In: Archeologie a vlastivěda. PhDr. Pavlu Michnovi k sedmdesátým narozeninám. VVM LXVI - Supplementum 2, 161-163. Brno.

REYNOLDS, A., 2009: Anglo-Saxon Deviant Burial Customs. In: Medieval History and Archaeology (Blair, J.-Hamerow, H., edd.). Oxford.

- 2014: Judicial culture and social complexity: a general model from Anglo-Saxon England. In: World Archaeology. Dostupné z http:/www.tandfonline.com/doi/full/10.1080/00438243.2013.878524, cit. 17. 2. 2016. DOI 10.1080/00438243.2013.878524

Richtstättenarchäologie, 2008: Richtstättenarchäologie (Auler, Jost, ed.). Dormagen.

Richtstättenarchäologie 2, 2010: Richtstättenarchäologie 2 (Auler, Jost, ed.). Dormagen.

Richtstättenarchäologie 3, 2012: Richtstättenarchäologie 3 (Auler, Jost, ed.). Dormagen.

ROUČKA, B., 1957: Poznámky k mapě hrdelních soudů v Čechách v první a ve druhé polovině 18. století, Právně historické studie 3, 115-133.

SOKOL, P., 2003: Šibenice v Bečově nad Teplou a archeologie popravišt' - The gallows at Bečov nad Teplou and the archaeology of places of execution, AR LV, 736-766.

- 2003a: Šibenice v Bečově nad Teplou, hrdelní soudnictví a archeologie. In: Západočeský historický sborník 8, 101-127. Plzeň.

- 2008: The Gallows at Bečov nad Teplou, District of Karlovy Vary, Czech Republic - Research, Conservation, Presentation. In: Richtstättenarchäologie (Auler, J., ed.), 250-269. Dormagen.

- 2008a: Trest, strach a neúcta. Pohřební ritus odsouzenců, Dějiny a současnost, č. 3, $24-27$.

- 2010: Gallows and Beheading Places in Pilsen. On Using Pictorial, Cartographic, Written and Archaeological Sources. In: Richtstättenarchäologie 2 (Auler, J., ed.), 348-373. Dormagen.

- 2010a: Ke sporu o interpretaci čelákovických hrobů „s projevy vampyrismu“. Jistoty a nejistoty (nejen) archeologických pramenů, Středočeský sborník historický 36, 134-155.

- 2010b: Měla Plzeň stínadla? Interpretace dosud neznámé městské stavby. In: Dějiny staveb. Sborník příspěvků z konference Dějiny staveb 2009, 9-16. Plzeň.

- 2010c: Suicide, vampire and delinquent. Burial practice as a form of social exclusion. In: Richtstättenarchäologie 2 (Auler, J., ed.), 148-173. Dormagen.

- 2011: Šibenice u Přimdy, okres Tachov. Z výsledků systematického povrchového průzkumu šibeničních vrchů západních Čech, AZČ 2, 182-188.

SOKOL, P.-HAJŠMAN, J., 2009: Plzeňská „spravedlnost““. Lokalizace a proměny zaniklé městské stavby. In: Dějiny staveb. Sborník př́íspěvků z konference Dějiny staveb 2008, 155-170. Plzeň.

- 2010: Po stopách plzeňské spravedlnosti. Historie a topografie hrdelního soudnictví. Domažlice.

ŠPAČEK, J., 2009: Poznámky k nové interpretaci pohřebiště s projevy vampyrismu a několik poznámek k otázce soudnictví městečka Čelákovic, Středočeský sborník historický 35, 185-208.

ŠTEFAN, I., 2009: Frühmittelalterliche Sonderbestattungen in Böhmen und Mähren. Archäologie der Randgruppen? Ethnographisch-Archäologische Zeitschrift 50, Heft 1-2, 139-162. 
UNGER, J., 2014: Tišnovská šibenice. In: Archeologie a vlastivěda. PhDr. Pavlu Michnovi k sedmdesátým narozeninám. VVM LXVI - Supplementum 2, 152-160. Brno.

VOKÁC̆, I., 2011: Zajímavý objekt u jihočeské Volyně, Pomniki dawnego prawa 14, 70-73.

- 2014: Popraviště v Jáchymově - Miejsce straceń w Jáchymově, Pomniki dawnego prawa 26, 60-69.

WOJTUCKI, D., 1999: Szubienice w województwie dolnośląskim. Wrocław.

- 2005: Popraviště v Čechách a na Moravě od 16.-19. století. In: Sborník Společnosti pro výzkum kamenných křižů $27-41$. Aš.

- 2009: Publiczne miejsca straceń na Dolnym Śląsku od XV do połowy XIX wieku. Katowice.

- 2014: Kat i jego warsztat pracy na Śląsku, Górnych Łużycach i w hrabstwie kłodzkim od początku XVI do połowy XIX wieku. Warszawa.

Nepublikované zprávy

KUNEŠ, P., 2015: Přimda, šibenice. Popis a rozbor malt, dokumentace. Protokol technologické laboratoře NPÚ GnŘ v Praze, rkp. ulož. v NPÚ ÚOP v Plzni.

SOKOL, P., 2015: Přimda, okr. Tachov - šibenice. Zjištovací archeologický výzkum v roce 2014. Nálezová zpráva, č. akce v IDAV 49620, rkp. ulož. v NPÚ ÚOP v Plzni.

ŠNEBERGER, J., 2014: Přimda. Antropologická zpráva, rkp. ulož. v NPÚ ÚOP v Plzni.

\section{Internetové zdroje}

ČESKÁ GEOLOGICKÁ SLUŽBA, mapové aplikace, http://www.geology.cz/app/ciselniky/lokalizace/ show_map.php?mapa $=\mathrm{g} 50 \& \mathrm{y}=873725 \& \mathrm{x}=1070989 \& \mathrm{~s}=1$, cit. 2. 3. 2016.

\section{Zusammenfassung}

Ein Galgen bei Přimda. Archäologische Ausgrabung eines Objektes von besonderer symbolischer und sozialer Bedeutung

Die Überreste von Galgen sind spezielle Objekte von großer symbolischer und ausgeprägter sozialer Bedeutung. Galgen bildeten dank ihrer absichtlich auffälligen Platzierung im Hinterland von einer Reihe von Städten Landschaftsdominanten und wurden hinsichtlich ihres Zwecks prägnant als ein Ort mit sittlich und rechtlich abgegrenzten Regeln für die Betriebsamkeit und den Kontakt der Bevölkerung mit dem eigentlichen Objekt Galgen wahrgenommen. In diesem Sinne war ein Galgen in der nächsten Umgebung einerseits ein Ort, an dem die Ordnung wiederhergestellt wurde, die durch das jeweils bestrafte Delikt verletzt wurde und andererseits dann ein Ort, der außerhalb von Hinrichtungen als verpönt und schändlich angesehen wurde. Im Symbolgehalt einer Hinrichtungsstätte ist enthalten, dass man Strafe nicht nur als Demonstration von Macht und Recht empfand, sondern auch als öffentliche Vorstellung, die besonders seit der Barockzeit gar Volksfestcharakter annehmen konnte. Gleichzeitig handelte es sich um einen Ort, der mit abergläubischen Vorstellungen und volkstümlicher Magie einherging, was in einem engen Zusammenhang mit dem Charakter des Ortes stand, an dem Menschen um ihr Leben gebracht wurden und man die Leiber von Selbstmördern verscharrte. Gerade das Begraben der Leiber von hingerichteten Personen oder Selbstmördern hat, obgleich dies mit minimalem bzw. oft ohne irgendeinen Ritus im engeren Sinne erfolgte und demnach den Charakter einer eigentümlichen Begräbnisstätte für die nächste Umgebung prägte, eine weitere Kompononte des Symbolgehalts von mittelalterlichen und besonders frühneuzeitlicher Hinrichtungsstätten ausgemacht. In der sozialen Sphäre repräsentieren Galgen Objekte mit ausgeprägter Bindung an einige soziale Gruppen und Berufssparten. Lässt man die Beteiligung der Zunftangehörigen des Bauhandwerks außer Acht, die an der Errichtung und an Reparaturarbeiten der Galgen beteiligt waren, war ein solcher Ort ausschließlich die Wirkungsstätte von Henkern, d.h. eine der seitens der übrigen Bevölkerung als am widersprüchlichsten empfundenen Berufsgruppen. Mit den Vollstreckungsformen von Todesstrafen (am häufigsten durch Erhängen) dienten die Galgen 
in Anknüpfung an den Charakter der bestraften Delikte für gewöhnlich nicht zur Bestrafung aller sozialer Gruppen. Der Galgen kann demnach aus den oben genannten Gründen als kulturell und sozial prägnant empfundenes Objekt ansehen, wozu auch die bisherigen archäologischen Feststellungen keinen Widerspruch bilden.

Im September 2014 erfolgte die Ausgrabung von Relikten eines Galgens bei Přimda im Bezirk Tachov (Westböhmen), die während einer 2006 erfolgten Untersuchung entdeckt wurden. Im Jahr 2011 wurden Grundangaben über die Fundstelle und die Einbettung in den historischen Kontext sowie die Forschung über solche frühneuzeitlichen Objekttypen veröffentlicht. Ziel der Untersuchung von 2014 war es, grundlegende Erkenntnisse über den Erhaltungsgrad des Reliktes hinsichtlich Bau, Stratigraphie und Fundpotenzial der Fundstelle in Anknüpfung an das Vorhaben der Stadt zu gewinnen, diesen Ort touristisch zu erschließen. Der Galgen befindet sich ca. $1 \mathrm{~km}$ südlich von Přimda auf dem waldbedeckten Galgenberg (Šibeník) in einer Höhe von 755 m ü.d.M. Die von der Pilsener Fachstelle des Nationalen Denkmalinstituts in Zusammenarbeit mit dem Museum des Böhmerwaldes von Tachov durchgeführte Untersuchung erfolgte in Form von sechs Sondierungsgrabungen, die innerhalb und außerhalb eines fast runden mit Steinen gemauerten Objektes verteilt waren, dessen Gemäuer leicht aus dem Gelände herausragten und von Schutt verdeckt waren. Die Sondierungsgrabungen wurden bis zum Niveau des gewachsenen Untergrundes ausgehoben, an einigen Stellen bis unter das Niveau der bis in den Untergrund reichenden Fundamentfugen. Der Galgen hatte einen unregelmäßigen runde Grundriss mit einem Außendurchmesser von ca. 6,2 $\mathrm{m}$ bei einer sich zwischen 0,63 und 0,72 m bewegenden Gemäuerstärke. Das Gemäuer des Galgens ist bis zur Höhe von ca. $1 \mathrm{~m}$ ab der Fundamentfuge erhalten geblieben. Den Galgen betrat man von der Nordostseite durch einen 0,75 m breiten Eingang, Reste der Türkonstruktion, die dort zwangsläufig gewesen sein mussten, konnten durch die Grabung nicht belegt werden. Der Bau wurde aus Bruchsteinen auf Mörtel gemauert und offenbar von außen und von innen verputzt sowie mit einem Kalkanstrich versehen. Ziegelsteinfragmente deuten darauf hin, dass manchmal auch dieses Material Verwendung fand. Der ursprünglich mehrere Meter hohe Holzbalken wurde von vier Pfeilern getragen, die auf der Innenseite aus der Außenmauer hervortraten, von denen zwei einander gegenüberstehende bei der Grabung freigelegt wurden. Die Stratigraphie deutet eher darauf hin, dass das Objekt nach und nach immer mehr verfiel, um schließlich in der Zerstörung zu enden.

Die Grabung lieferte auch Belege der materiellen Kultur, die mit dem Betrieb des Objektes zusammenhängen und in seinem Inern und im Raum vor dem Eingang konzentriert waren: 177 kleine Keramikbruchstücke, von denen die meisten von drei zertrümmerten Gefäßen auf dem Niveau der damaligen Geländeoberfläche stammen, der Teil eines Löffels, Kleiderschließen (Häkchen, ein Knopf, eine Nadel), Militaria (durch Aufprall verformte Bleikugel), Bestandteile der Baukonstruktion (Nägel, eine Öse). Insgesamt wurden bei der Grabung 17 Metallgegenstände oder Bruchstücke von ihnen entdeckt. Zu den typischen Funden zählen menschliche Knochen von nicht bestatteten Verurteilten. Bei ihnen handelt es sich um 18 isolierte Knochen, unter denen sich kein einziger befand, der sich für eine grundlegende demographische Schätzung oder für eine Berechnung der Mindestanzahl an Indiviuen eignete. Vertreten sind jedoch Knochen von allen Körperteilen - Schädel, Wirbelsäulen, vom Brustkorb und den Extremitäten.

Bei der Festlegung der Datierung des Galgens kann man sich sowohl an die entdeckten beweglichen Funde, als auch an schriftliche Erwähnungen halten, die den Vollzug von Todesstrafen in Přimda betreffen. Beides liefert jedoch lediglich grobe Anhaltspunkte. Die Funde repräsentieren das übliche frühneuzeitliche Inventar, dass man wahrscheinlich dem 17., sicherer jedoch dem 18. Jahrhundert zuordnen kann. Während die Kleiderhäkchen gängige Kleiderschließen repräsentieren, handelt es sich bei den weniger zu erwartenden Gegenständen um einen Löffel (ohne den ursprünglich angenieteten Griff), der offenbar zusammen mit den kleineren Keramikgefäßen die Verpflegung während den Arbeiten am Galgen belegt, und um eine benutzte Kugel, deren Verbundenheit mit dem Objekt des Galgens eher zufällig ist.

Galgen vom Typ wie er in Přimda in Gebrauch war, wurden im Zeitraum vom 16.-18. Jahrhundert gebaut. Obwohl Přimda bereits viel früher über eine Halsgerichtsordnung verfügt hat, 
sind aus den schriftlichen Quellen bislang nur Erwähnungen von Todesstrafen aus der ersten Hälfte des 18. Jahrhunderts bekannt, wobei lediglich eine Angabe aus dem Jahr 1726 konkret eine Strafe durch Erhängen betrifft, deren Vollzug eindeutig mit dem Galgen in Verbindung gebracht werden kann. Die Funde und die schriftlichen Nachrichten ermöglichen es demnach, den untersuchten Galgen mit Sicherheit in das 18. Jahrhundert zu datieren, wobei das Ende der Halsgerichtsrechtssprechung und damit auch für den Betrieb des Galgens für Přimda, ebenso wie auch in vielen anderen Fällen, die Reform des Halsgerichtswesens aus dem Jahr 1765 darstellte.

Mgr. Petr Sokol, Národní památkový ústav, územní odborné pracoviště v Plzni, Prešovská 7 , 30100 Plzeň, Česká republika, sokol.petr@npu.cz 
